\title{
PREDIÇÃO DO COMPORTAMENTO DE HÍBRIDOS DE BERINJELA POR MEDIDAS DE DIVERGÊNCIA GENÉTICA
}

DERLY JOSÉ HENRIQUES DA SILVA

Engenheiro Agrônomo

Orientador: Prof. Dr. CYRO PAULINO DA COSTA

Tese apresentada à Escola Superior de Agricultura 'Luiz de Queiroz", Universidade de São Paulo, para obtenção do título de Doutor em Agronomia, Área de concentração: Genética e Melhoramento de Plantas.

PIRACICABA

Estado de São Paulo - Brasil

Fevereiro - 1999 
Dados Internacionais de Catalogação na Publicação (CIP) DIVISÃO DE BIBLIOTECA E DOCUMENTAÇÃO - Campus "Luiz de Queiroz"/USP

Silva, Derly José Henriques da

Predição do comportamento de hibridos de berinjela por medidas de divergência genética / Derly José Henriques da Silva. - - Piracicaba, 1999.

90 p. : il.

Tese (doutorado) - Escola Superior de Agricultura Luiz de Queiroz, 1999.

Bibliografia.

1. Análise combinatória 2. Análise genética 3. Berinjela hibrida 4. Divergência genética 5. Legume 6. Melhoramento genético vegetal I. Titulo 
PREDIÇÃO DO COMPORTAMENTO DE HÍBRIDOS DE BERINJELA POR MEDIDAS DE DIVERGÊNCIA GENÉTICA

DERLY JOSÉ HENRIQUES DA SILVA

Prof. Dr. CYRO PAULINO DA COSTA

Orientador 
À Deus e aos Amigos Espirituais pelos resquícios de equilíbrio que desfruto. Aos meus pais que sempre estão ao meu lado. Aos meus sogros-pais, pelo entusiasmo e amor que me dedicam. À Flavinha, minha filha do coração e a Bruno meu filho.

$\grave{A}$ aquela que me acompanha desde a eternidade..., com seu amor e alegria, sem a qual nada se concretizaria. Minha Kit,

Doralice,

Dorinha. 


\section{AGRADECIMENTOS}

À Universidade Federal de Viçosa (UFV), pela liberação para a realização deste curso.

Aos professores do Departamento de Fitotecnia, especialmente aos colegas do setor de Olericultura, que viabilizaram a licença para a realização deste curso.

Aos amigos Tocio e Cidinha Sedyiama, mais que procuradores, fiéis e verdadeiros amigos.

À Coordenação de Aperfeiçoamento de Pessoal de Ensino Superior, (CAPES/PICDT), pela concessão de bolsa.

À Escola Superior de Agricultura "Luiz de Queiroz" (ESALQ/USP) pela oportunidade oferecida para realização do curso.

Ao Professor Doutor Cyro Paulino da Costa pela orientação e ensinamentos.

Ao Professor Vicente Wagner Dias Casali, pelos aconselhamentos, ensinamentos, amizade e estímulo sempre presentes.

Ao Professor Cosme Damião Cruz, pelos aconselhamentos, ensinamentos e amizade.

Ao Doutor Luiz Antônio dos Santos Dias, pela amizade, pelos ensinamentos e valiosas sugestões na elaboração deste trabalho e dos artigos relacionados.

Aos Professores Doutores Natal Antônio Vello e Gerhard Bandel pelo acompanhamento e estímulos durante 0 curso e pelas sugestões apresentadas.

Aos funcionários do Departamento de Genética especialmente ao Rudinei, as secretárias e bibliotecárias.

Aos colegas do curso de pós-graduação em Genética e Melhoramento de Plantas do Departamento de Genética da ESALQ/USP pela 
amizade e companheirismo, que foram fundamentais para o êxito deste trabalho.

A Rosângela, Grabriel Deon, Luis Cláudio, Luciana, Angela, Rogério e Luciana pela amizade que sempre nos unirá.

Aos amigos Paulo Moraes e D. Wilma, que me abriram as portas da cidade de Piracicaba.

Aos amigos piracicabanos pela acolhida, amizade e carinho, e de modo especial ao Sr. Rubens, Maria Cleuza, D. Lúcia, Nairzinha e Bê.

Aos amigos viçosenses pelo estímulo e confiança, especialmente a Mazzarello, Lyderson e Silayne. 


\section{SUMÁRIO}

Página

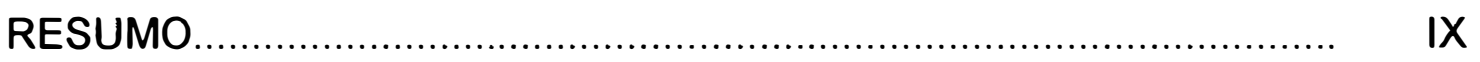

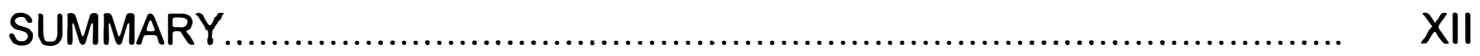

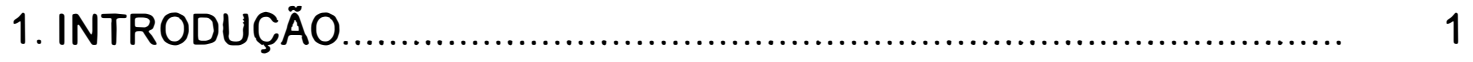

2 REVISÃO DE LITERATURA ...................................................... 4

2.1 Divergência genética............................................................... 4

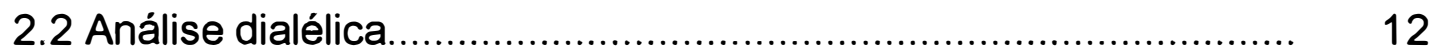

2.3 Associação entre divergência genética de genitores e comportamento de híbridos.

3. Cap. I: ESTABILIDADE DA DIVERGÊNCIA GENÉTICA ENTRE ACESSOS DE BERINJELA EM TRÊS ESTÁDIOS DO DESENVOLVIMENTO .................................................................

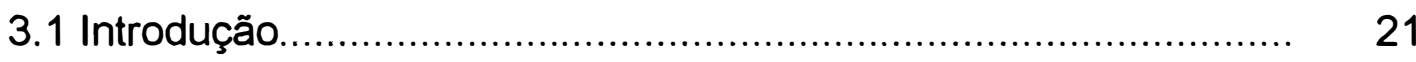

3.2 Material e métodos ................................................................. 23

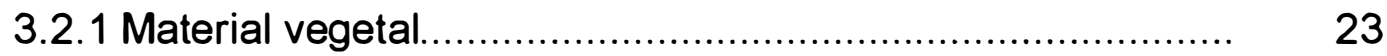

3.2.2 Avaliação de campo........................................................ 23

3.2.2.1 Caracteres vegetativos .............................................. 25

3.2.2.2 Caracteres reprodutivos ............................................. 26

3.2.2.3 Caracteres produtivos .............................................. 28

3.2.3 Análise estatística....................................................... 29

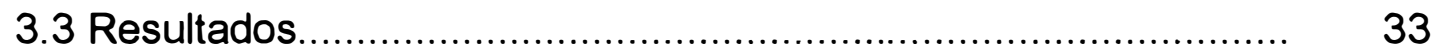


3.3.1 Estádio Vegetativo

3.3.2 Estádio reprodutivo.

3.3.3 Estádio produtivo

3.4 Discussão.

4. Cap. II: ANÁLISE DA CAPACIDADE COMBINATÓRIA EM BERINJELA...

4.1 Introdução.

4.2 Material e métodos.

4.3 Resultados e discussão.

5. Cap. III: RELAÇÃO ENTRE DIVERGÉNCIA GENÉTICA DE GENITORES E DESEMPENHO DE HÍBRIDOS DE BERINJELA

5.1 Introdução.

59

5.2 Material e métodos. 60

5.3 Resultados e discussão.. 64

6. CONCLUSŐES 74 REFERÊNCIAS BIBLIOGRÁFICAS. 76 


\title{
PREDIÇÃO DO COMPORTAMENTO DE HÍBRIDOS DE BERINJELA POR MEDIDAS DE DIVERGÉNCIA GENÉTICA
}

\author{
Autor: DERLY JOSÉ HENRIQUES DA SILVA \\ Orientador: Prof. CYRO PAULINO DA COSTA
}

\section{RESUMO}

As técnicas multivariadas têm sido utilizadas no melhoramento de plantas para a estimação da divergência genética entre unidades amostrais, principalmente na seleção de genitores para programas de melhoramento que envolvem hibridações. Por outro lado, a estimação de parâmetros genéticos mediante o uso da análise dialélica também pode ser utilizada para selecionar genitores. Neste sentido, Kempthorne \& Curnow (1961) desenvolveram o método do dialelo circulante, que não necessita de todas as combinações hibridas, feitas aos pares, para se avaliar um conjunto de genitores.

Com o objetivo geral de avaliar a utilização de técnicas multivariadas na estimação da divergência genética e a eficiência da predição do comportamento de hibridos de berinjela a partir da divergência genética entre genitores, realizou-se o presente trabalho, com os seguintes objetivos especificos:

1) estudar a estabilidade da divergência genética entre acessos de berinjela em três estádios do desenvolvimento da planta; 2) analisar a capacidade combinatória de cinco acessos de berinjela mediante o uso da análise dialélica 
circulante, com dois híbridos por genitor; e 3) estudar a associação da divergência entre genitores com o desempenho dos híbridos.

A estabilidade da divergência genética foi analisada a partir de 29 caracteres, divididos em três estádios do desenvolvimento da planta (vegetativo, reprodutivo e produtivo). Foram formados dois grupos de acessos no estádio vegetativo, quatro no reprodutivo e seis no produtivo. Assim, os caracteres do estádio produtivo possuem maior capacidade de discriminação dos acessos analisados.

Observou-se, por outro lado, a inconsistência quanto ao número e à composição dos grupos formados nos diferentes estádios, significando que a divergência genética, entre acessos, é especifica para o conjunto de caracteres do estádio utilizado para a sua estimação.

Em relação à análise combinatória, empregando-se o dialelo circulante, pôde-se concluir que existe predominância dos efeitos gênicos aditivos em todos os caracteres analisados, a saber: comprimento médio de frutos, diâmetro médio de frutos, peso médio de frutos, número médio de frutos por planta e produção total de frutos por planta.

Com base nas estimativas de capacidade geral de combinação (CGC), os acessos PI 206472 e 'Campineira' foram indicados para programas de melhoramento intrapopulacional. Dentre os hibridos analisados e preditos, PI 206472 x 'Campineira', PI 206472 x 'Florida Market', PI 206472 x 'E-22', e 'Campineira' x 'E-22' apresentaram potencial para exploração comercial.

A associação entre divergência genética dos genitores e desempenho dos híbridos foi analisada por três métodos - 1) Correlações de Pearson $\left(r_{P}\right)$ e Spearman $\left(r_{S}\right) ; 2$ ) Separação da divergência genética em classes; e Classificação dupla. Os resultados foram: Método 1 - foi eficiente, pois observou-se que a divergência $\left(D^{2}\right)$ está linearmente associada ao desempenho médio dos hibridos para o caráter número médio de frutos por planta $\left(r_{P}=0,71\right.$ e $\left.r_{S}=0,636, P<0,05\right)$ e inversamente relacionada à produção 
total de frutos por planta (gramas/planta) ( $\left.r_{\mathrm{P}}=-0,687, \mathrm{P}<0,05\right)$; Método 2 - foi promissor, pois selecionou os cruzamentos PI 206472 x 'Florida Market' e 'Campineira' x 'Florida Market', cujos híbridos ocuparam a segunda e a terceira posição, respectivamente, na classificação das médias dos híbridos; Método 3 mostrou-se eficiente, pois, a partir da classificação do desempenho dos genitores e da divergência entre estes, selecionou o cruzamento PI 206472 x 'Florida Market', cujo híbrido obteve a segunda posição na soma de postos de classificação das médias, superando os híbridos 'Nápoli' e 'Super F100', que são cultivados comercialmente. 


\title{
PREDICTION EGGPLANT HYBRIDS PERFORMANCE BASED ON GENETIC DIVERGENCE
}

\author{
Author : DERLY JOSÉ HENRIQUES DA SILVA \\ Adviser: Prof. CYRO PAULINO DA COSTA
}

\section{SUMMARY}

The multivariate techniques have been used in plant breeding to estimate genetic divergence among sampling units, mainly to select parents for breeding programs involving hybridization. Estimation of genetic parameters by means of diallel analysis can also be used to select parents. For this purpose, Kempthorne \& Curnow (1961) have developed the partial diallel cross method, which does not need all the hybrid combinations, made by pairs to evaluate a set of parents.

This work was carried out to evaluate the use of multivariate techniques to estimate genetic divergence and the effectiveness of predicting eggplant hybrids behavior based on genetic divergence among parents, having the following specific objectives;

1) to study genetic divergence stability among eggplant accesses in three stages of plant development; 2) to analyze the combining ability of five eggplant accesses by use of partial diallel cross analysis, using two hybrids per parent; and 3) to study the association of parent divergence with hybrid performance.

Genetic divergence stability was analyzed from 29 characters grouped into three plant development stages (vegetative, reproductive and productive). Two access groups were formed in the vegetative stage, four in the 
reproductive stage and six in the productive stage. Thus, the productive stage characters have greater capacity to discriminate the accesses analyzed.

Number and composition of the groups formed in the different stages were found to be inconsistent, which means that genetic divergence among accesses is specific for the set of characters of the stage used for its estimation.

In relation to the combining analysis by means of partial diallel cross, it could be concluded that there is a predominance of additive genic effects in all the characters analyzed, namely: fruit average length, fruit average diameter, fruit average weight, average number of fruit per plant and fruit production per plant.

Based on estimates of general combining capacity (GCC), the accesses PI 206472 and "Campineira" were indicated for use in intrapopulational breeding programs. Among the analyzed and predicted hybrids, PI 206472 x 'Campineira', PI 206472 x 'Florida Market', PI 206472 x 'E22', and 'Campineira' $\times$ 'E-22' presented potential for commercial application.

The association between genetic divergence and hybrid performance was analyzed by three methods - 1)Pearson $\left(r_{p}\right)$ and Spearman $\left(r_{s}\right)$ correlations; 2) division of genetic divergence by class; 3 ) double classification method.

Method 1 was considered efficient since divergence $\left(D^{2}\right)$ was found linearly associated with average hybrid performance for the character average hybrid performance for the character average number of fruit per plant $\left(r_{P}=0,71\right.$ e $r_{s}=$ $0,636, P<0,05)$ and inversely related to fruit production per plant (grams/plants) $\left(r_{P}=-0,687, P<0,05\right)$; Method 2 was considered promising for it could select the crosses PI 206472 x 'Florida Market' and 'Campineira' x 'Florida Market', whose hybrids were placed second and third, respectively, in hybrid average classification; Method 3 was found to be efficient for, based on parent performance and divergence between them cross PI 206472 x 'Florida Market' could be selected with its hybrid ranking second in the sum of average 
classification, overcoming the hybrids 'Nápoli' and 'Super F100', which are cultivated for commercial purposes. 


\section{INTRODUÇÃO}

A berinjela (Solanum melongena L.) constitui uma das mais importantes solanáceas utilizadas como hortaliça. O crescente interesse da população em consumir produtos de origem vegetal, livres de calorias excessivas e de colesterol, tem aumentado o consumo desta hortaliça.

Segundo Noda (1980), a unidade do CEAGESP, em São Paulo, comercializou 728 mil caixas (14 kg) no ano de 1970. Em 1978 foram registrados um milhão de caixas comercializadas. No ano de 1994 (Boletim mensal CEAGESP, 1994) foram comercializados mais de dois milhões de caixas, que representam aproximadamente 25 mil toneladas do produto.

O mercado brasileiro de berinjela é dominado pelos híbridos, por serem produtivos, uniformes, homeostáticos e atenderem às exigências dos consumidores quanto a cor, brilho e formato (Noda, 1980).

Os híbridos de berinjela são obtidos a partir do cruzamento de linhagens parentais selecionadas, a fim de que exigências tais como uniformidade dos frutos quanto a cor, brilho e formato possam ser atendidas. Entretanto quanto ao modo de reprodução, Costa \& Pinto (1977) classificam a berinjela como espécie intermediária, entre autógamas e alógamas, pois sua taxa de fecundação cruzada natural varia de 0,2 a $46,8 \%$, o que garante a existência de variabilidade entre os acessos desta cultura. Portanto, na escolha de acessos para a obtenção de linhagens a serem utilizadas como genitores para futuros híbridos, é necessária a avaliação de grande número de acessos 
para selecionar os que reúnam rendimento satisfatório, que atendam às exigências do consumidor (Cruz, 1990) e que possibilitem a obtenção de hibridos heteróticos. Esta última qualidade se consegue quando se cruzam genitores divergentes.

A divergência genética pode ser avaliada por meio de técnicas quantitativas, como os dialelos, e preditivas, como as análises multivariadas (Miranda et al., 1988).

A análise dialélica tem por finalidade prover estimativas de parâmetros genéticos úteis na seleção de genitores, para hibridação, e no entendimento dos efeitos genéticos envolvidos na determinação dos caracteres. Os dialelos completos, apesar de terem bases matemáticas já demonstradas, apresentam 0 inconveniente de exigirem que todos os genitores, sob análise, sejam cruzados aos pares. Neste sentido, Kempthorne \& Curnow (1961) apresentaram o dialelo circulante, que exige número menor de hibridações por genitor que os dialelos completos.

A utilização das técnicas multivariadas na estimação da divergência genética, é feita a partir de dados relativos a caracteres qualitativos, quantitativos, morfológicos, fisiológicos, isoenzimáticos (Dias, 1998), e moleculares (Ferreira \& Grattapaglia, 1995), sem a necessidade de produzir e avaliar os híbridos entre estes. A fase de avaliação dos híbridos pode ser feita apenas para os genitores mais divergentes e que apresentem bom desempenho quanto aos caracteres avaliados (Maluf et al., 1983).

Em razão do exposto, desenvolveu-se o presente trabalho baseando-se nas hipóteses de que a divergência genética entre acessos varia em função do estádio de desenvolvimento avaliado e de que é possível estabelecer uma metodologia eficiente para predizer o comportamento dos hibridos de berinjela a partir da divergência genética entre genitores, sem que seja necessária a obtenção dos híbridos entre estes, como acontece na análise dialélica. 
Para investigar as hipóteses, mencionadas anteriormente, esta tese foi dividida em três capítulos, cujos objetivos foram:

- Avaliar a estabilidade da divergência genética entre 19 acessos de berinjela. Para tanto, foram avaliados caracteres biométricos em três fases do desenvolvimento das plantas: vegetativa, reprodutiva e produtiva.

- Fazer a análise dialélica de cinco genitores divergentes e avaliar seu potencial para exploração comercial, utilizando a metodologia de dialelo circulante proposta por Kempthorne \& Curnow (1961).

- Avaliar três métodos associativos do comportamento dos híbridos com a divergência genética dos genitores. A saber:

1) Correlação de Pearson e Spearman entre a divergência genética dos genitores e o rendimento médio dos híbridos respectivos;

2) Método de Arunachalan \& Bandyopadyay (1984), que seleciona genitores cujos cruzamentos são heteróticos a partir da separação da divergência genética entre genitores em classes; e

3) Método da classificação dupla, que seleciona cruzamentos a partir da classificação do desempenho dos genitores e da divergência genética entre aqueles de maior desempenho.

Para atingir tais objetivos foram apresentados três trabalhos, os quais são:

Estabilidade da divergência genética entre acessos de berinjela em três estádios do desenvolvimento.

Análise da capacidade combinatória em berinjela.

Relação entre divergência genética de acessos de berinjela e desempenho de seus hibridos. 


\section{REVISÃO DE LITERATURA}

\subsection{Divergência genética}

O termo divergência, do ponto de vista etimológico, significa linhas que se afastam progressivamente. Em termos genéticos, pode-se dizer que a divergência quantifica a dissimilaridade existente entre genótipos pertencentes a uma ou várias espécies.

A dissimilaridade entre populações pode ter diferentes origens, pois populações geneticamente separadas ao longo do processo evolutivo e submetidas às forças criadoras e ampliadoras de variabilidade (Ramalho et al., 1989) tendem a apresentar genes ou freqüências gênicas diferentes (Harlan, 1975). Dessa forma, ao longo do processo evolutivo, indivíduos geneticamente separados podem acumular genes cuja expressão os diferencia. Essas diferenças gênicas podem estar relacionadas à adaptação diferencial a determinados ambientes, tolerância a pragas e doenças, entre outras, gerando assim a divergência genética.

Wright (1978) demonstrou que a divergência genética entre duas populações, considerando um único loco, é igual à metade da soma das diferenças absolutas entre as freqüências alélicas das populações ( $x$ e $y$ ). Assim, sendo Ko número de alelos, tem-se:

$$
D_{x y}=0,5 \sum_{i=1}\left|q_{x_{i}}-q_{y_{i}}\right| \text {, }
$$


em que

$D_{x y}$ : divergência entre as populações $x$ e y;

$q_{x i}$ : freqüência de um determinado alelo i na população $x ; e$

$q_{y i}$ : freqüência do mesmo alelo i na população y.

A associação entre divergência genética e heterose foi estudada por Cress (1966), que trabalhou com populações de trigo com diferentes freqüências alélicas. Esse autor concluiu que a heterose detectada nos híbridos entre estas populações estava diretamente relacionada às diferenças de freqüências alélicas dos genitores. Atualmente sabe-se que a heterose observada em um cruzamento entre dois genitores particulares ou populações depende do quadrado da diferença de freqüência gênica entre estas e do efeito de dominância do caráter (Falconer \& Mackay, 1996).

Em relação à heterose, se populações não-divergentes forem cruzadas, não haverá heterose. Por outro lado, a heterose será máxima quando uma série de alelos de um conjunto de locos estiverem fixados em uma população, enquanto outros alelos, destes mesmos locos, estiverem fixados na outra população parental. Assim, heterose pode ser definida como:

$$
H_{F 1}=\Sigma d y^{2}
$$

em que

$H$ : heterose;

$F_{1}$ : progênie da primeira geração pós hibridação;

d : efeito de dominância, do caráter;

y : diferença de freqüência gênica entre as populações a serem cruzadas.

Estudos sobre divergência genética são de grande importância em programas de melhoramento envolvendo hibridações, por fornecerem parâmetros para a identificação de genitores que, quando cruzados, apresentam maior efeito heterótico na população filial e maior possibilidade de obtenção de genótipos superiores nas gerações seguintes (Cruz, 1990). 
Dessa forma, pode-se observar que a divergência genética entre genitores, pode ser inferida a partir da heterose que manifestam em uma série de cruzamentos dialélicos (Hallauer \& Miranda Filho, 1988).

Ferreira (1993), trabalhando com divergência genética em milho e sua associação com parâmetros genéticos estimados em cruzamentos dialélicos, sugeriu a utilização da capacidade específica de combinação para inferências a respeito da divergência genética entre genitores. Quando o número de genitores é superior a 15, mesmo utilizando a metodologia de dialelo parcial (Miranda Filho \& Geraldi, 1984) ou dialelos desbalanceados (Oliveira Júnior, 1995), as combinações híbridas são tantas que se torna difícil analisálas e interpretá-las (Hallauer \& Miranda Filho, 1988; Pacheco, 1997).

A análise quantitativa da divergência genética (Miranda, 1988), mediante análise dialélica, mostra ser inviável quando se trabalha com muitos genitores, como é característico do início de um programa de melhoramento. Esta metodologia é também inviável para analisar e caracterizar coleções de germoplasma, que possuem muitos genótipos registrados, os quais recebem a denominação de acessos (Valois, 1996).

A divergência genética pode ser estimada mediante a utilização da estatística multivariada, denominada por Miranda (1988) de análise preditiva da divergência genética. Essa estatística possibilita a obtenção das estimativas da divergência genética entre genitores, sem que para isto seja necessária a obtenção dos hibridos. Desse modo, o melhorista pode concentrar esforços nas combinações com maior probabilidade de possuirem efeito heterótico (Maluf et al., 1983).

A análise multivariada da divergência genética é unificadora, o que permite integrar informações de um conjunto de caracteres (Amaral Júnior, 1996). Assim, as técnicas multivariadas têm sido apresentadas como procedimentos eficientes no melhoramento de plantas, em razão de combinarem as múltiplas informações provenientes de uma unidade amostral (variedade, clone, população e linhagem) de modo que seja possivel selecionar 
ou predizer fenômenos genéticos baseando-se simultaneamente em um complexo de variáveis importantes dentro de um programa de melhoramento (Cruz, 1990). Dessa forma, tem-se a oportunidade de selecionar acessos divergentes com base no conjunto dos caracteres que compõem os objetivos do programa de melhoramento.

Diversas estatísticas multivariadas têm sido propostas para a quantificação da divergência genética entre acessos. Entretanto, a Distância Generalizada de Mahalanobis, por considerar as correlaçöes existentes entre os caracteres analisados (Rao, 1952), é muito utilizada, sendo possivel a sua utilização para dados com repetição (Cruz \& Regazzi, 1994).

A distância generalizada de Mahalanobis $\left(D_{i i}{ }^{2}\right)$ entre dois genótipos i e i' (Mahalanobis, 1936), foi definida como:

$$
D_{i i}{ }^{2}=d^{\prime} W^{-1} d
$$

em que

$d$ : vetor de diferenças entre médias dos acessos para todos os $p$ caracteres analisados;

$\mathrm{d}_{\sim}^{\prime}$ : transposto de $\underset{\sim}{\mathrm{d} ;} \mathrm{e}$

$W^{-1}$ : inversa da matriz $p \times p$ de variâncias e covariâncias residuais.

Para evitar a inversão da matriz $W$, podem-se transformar as variáveis originais em variáveis padronizadas e não-correlacionadas, mediante a utilização do processo de condensação pivotal (Rao, 1952).

Dentre as diferentes análises multivariadas, os métodos de agrupamentos obtidos a partir da Distância Generalizada de Mahalanobis $\left(D_{i i}{ }^{2}\right)$ são freqüentemente utilizados (Cruz \& Regazzi, 1994). Os métodos de agrupamento objetivam a reunião dos acessos em grupos, de forma que haja homogeneidade dentro e heterogeneidade entre os grupos (Mardia, 1979); assim, a variação é mínima dentro de cada grupo e máxima entre os grupos (Singh \& Chaudhary, 1979; Cruz, 1990). 
Segundo Gouder \& Yeomans (1973), a estratificação que é feita ao se agruparem os acessos, além de facilitar o processamento dos dados, é, em muitos casos, de grande praticidade no planejamento e execução das atividades dentro de um programa de melhoramento.

As técnicas de análise de agrupamento têm por finalidade dividir um conjunto original de observações em vários grupos homogêneos, segundo algum critério de dissimilaridade. Porém, na análise de agrupamento surgem várias questões: questiona-se o número final de grupos desejados, a adequação da partição obtida e o tipo de medida de similaridade a ser adotado.

Podem ser usadas diversas medidas de dissimilaridade (Cruz \& Regazzi, 1994). Entre as medidas de dissimilaridade, as mais comuns são as distâncias de Mahalanobis e a euclidiana.

A existência ou não de correlações residuais entre os caracteres pode influenciar a escolha da medida de dissimilaridade a ser adotada. Quando existem correlações residuais significativas, deve-se utilizar a distância generalizada de Mahalanobis $\left(D^{2}\right)$; porém, para usá-la, os dados devem seguir a distribuição normal multidimensional e pressupõe-se também homogeneidade da matriz de variâncias e covariâncias residuais, apesar de já Ter sido demonstrado que, mesmo quando algumas destas pressuposições não são satisfeitas, pode-se utilizar a distância generalizada de Mahalanobis (Sneath \& Sokal, 1973).

Existem critérios para que a classificação de acessos, seja eficiente, usando-se a distância generalizada de Mahalanobis, os quais são: $1^{0}$ - a distância não pode decrescer quando caracteres adicionais são considerados; $2^{\circ}$ - o incremento na distância pela adição de alguns caracteres a um grupo destes, já previamente e apropriadamente escolhido, deve ser pequeno, de modo a não alterar a classificação feita com base nos caracteres iniciais; $3^{\circ}$ - as variáveis devem apresentar distribuição normal (Arunachalan, 1981). 
Dentre os métodos de agrupamento, as técnicas de otimização produzem partição dos objetos, mas diferem das técnicas hierárquicas (vizinho mais próximo, vizinho mais distante, etc.), porque admitem a realocação dos materiais sob análise, possibilitando, portanto, que uma divisão ruim no início seja corrigida em estágios futuros. As técnicas de otimização são assim chamadas porque buscam a partição dos dados que otimizam (maximizam ou minimizam), por alguma medida predefinida (Bussab et al., 1990). Dentre estes, o método de otimização de Tocher (Rao, 1952), que adota o critério de manter a distância média dentro do grupo sempre inferior a qualquer distância entre os grupos, é atualmente um dos mais utilizados (Cruz \& Regazzi, 1994).

Bhandari (1991) trabalhou com 100 genótipos de Vigna aconitifolia e agrupou-os em sete grupos, mediante a utilização da distância euclidiana média, analisando caracteres morfológicos e componentes de produção. Por esta técnica, foram alojadas nos mesmos grupos linhagens relacionadas, mantendo-se a similaridade morfológica dentro de cada grupo. A distribuição geográfica não coincidiu com a distribuição dos genótipos em grupos, segundo a técnica utilizada.

Na região de Budapeste, Hungria, existem diversas raças locais de Phaseolus coccineus. Zeven et al. (1993) utilizaram 27 características morfológicas e fisiológicas, empregando análise de componentes principais e $D^{2}$ (Mahalanobis), e conseguiram separar um conjunto destas raças em cinco grupos.

Tcacenco \& Lance (1992) trabalhando na Estação Experimental de Itajaí-SC, com nove acessos de Pennisetum purpureum, mediante a utilização de 89 caracteres, sendo 64 vegetativos (antes da emissão da inflorescência) e 25 reprodutivos (após a emissão da inflorescência), fizeram análise de variância dos dados empregando também componentes principais e análise de agrupamento. Dos 25 caracteres reprodutivos analisados, a utilização de apenas sete foi eficiente na separação dos acessos. 
Avatar et al. (1991) trabalharam com Cuminum cyminum em um total de 30 linhagens, sendo 27 de Rajasthan, uma de Gujarat, uma do Egito e uma da Líbia. As linhagens foram avaliadas no período de 1987-1988. Com base nos dados de 13 características morfológicas, a divergência genética foi estimada utilizando-se a técnica $D^{2}$, e os genótipos foram agrupados em cinco grupos. Os grupos 1 e 2 apresentaram pequena distância entre si e continham 24 e três genótipos, respectivamente, sendo todos da província de Rajasthan. As linhagens da Líbia e do Egito foram agrupadas separadamente. Segundo os autores, isto sugere que existe relação entre diversidade genotípica e geográfica. Os caracteres que mais contribuíram para a divergência das linhagens foram produção de grãos e número de dias para o florescimento.

Maluf et al. (1983), trabalhando com um grupo de variedades de tomate, analisaram as seguintes características: produção total de frutos, número total de frutos, peso médio de frutos, peso médio de frutos comercializáveis, porcentagem de produção precoce, porcentagem de frutos rachados, número de cachos/planta, número de frutos/cacho, peso da planta, peso do $1^{\circ}$ cacho e número de internós/planta. Com os dados, calculou-se a distância euclidiana e a estatística $D^{2}$ de Mahalanobis. Os autores observaram correlação média de $72 \%$ entre divergência e heterose para produção e concluíram que as análises multivariadas da divergência genética entre cultivares pode permitir razoavelmente boa predição da resposta heterótica em hibridos de tomate. Este procedimento seria muito útil nos passos iniciais de um programa de melhoramento, quando grande número de acessos pode ser testado, com relação a muitas características. Os cruzamentos se limitariam às combinações mais divergentes.

Oliveira (1997), trabalhando com seleção de genótipos de pimentão, visando adaptação a ambientes com baixos teores de fósforo $(P)$, analisou a divergência genética existente entre 133 acessos do banco de germoplasma de hortaliças da Universidade Federal de Viçosa, a partir de um conjunto de caracteres relacionados à produção de frutos. Com base na 
divergência detectada, foram selecionados acessos para cruzamentos dialélicos, a fase posterior do programa de melhoramento.

Atualmente, as análises multivariadas estão sendo utilizadas na avaliação da dissimilaridade genética entre acessos de bancos de germoplasma (Spagnoletti Zeulli \& Qualset, 1993) e para a identificação de acessos duplicados, os quais, apesar de representarem o mesmo genótipo, por razões desconhecidas, recebem dupla numeração nos registros dos bancos de germoplasma. Neste sentido, Dias et al. (1993) estudaram a divergência existente entre 58 acessos de couve-portuguesa, coletados junto a agricultores de oito regiões diferentes. Os autores concluíram que os acessos foram distribuídos em oito grupos, segundo a localização dos agricultores; e portanto, as diferentes denominações dadas eram mais influenciadas por variações ambientais que genéticas.

Outra utilidade da divergência genética se verifica em estudos de estruturação de coleções nucleares, que são coleções de germoplasma com 10 a $15 \%$ do tamanho da coleção original e que representam 70 a $80 \%$ da variabilidade genética disponivel na espécie de interesse e nos parentes silvestres (Valois et al., 1996). Neste sentido, Holbrook et al. (1993) trabalhando com 7.432 acessos do Banco de Germoplasma de amendoim dos Estados Unidos da América, reuniram resultados de diferentes experimentos com caracteres morfológicos e, a partir destes, montaram uma coleção nuclear com 831 acessos. Também Spagnoletti Zeuli \& Qualset (1993), analisando 3.000 acessos de trigo duro, a partir de quatro caracteres qualitativos e oito quantitativos relacionados à espigueta, concluíram que $80 \%$ da variabilidade poderia ser reunida com 500 acessos.

Em berinjela, Singh et al. (1995) utilizaram a distância generalizada de Mahalanobis e os métodos de agrupamento para caracterizar a divergência existente entre 65 acessos de diferentes origens, a partir de dez caracteres relacionados à produção. Os autores concluíram que os grupos formados não tiveram relação com a origem ecogeográfica dos acessos. Em relação a isso, 
Tambe et al. (1995), trabalhando com 25 acessos de berinjela, observaram que o padrão de agrupamento não apresentou relação com a origem geográfica dos materiais analisados.

Karihaloo et al. (1995), mediante a utilização de RAPD, analisaram 52 acessos cultivados de Solanum melongena e 25 formas silvestres desta espécie, conhecidas como formas insanum. Com 22 sondas, obtiveram 130 fragmentos amplificáveis, sendo que os acessos cultivados apresentaram 117 fragmentos destes e as formas insanum apresentaram todos os 130 fragmentos. Apesar de as formas insanum serem muito divergentes, do ponto de vista morfológico, a similaridade entre estas e os acessos cultivados foi de $95 \%$. Os resultados obtidos utilizando-se RAPD foram similares àqueles obtidos por meio de análise de isoenzimas. A análise de similaridade permitiu concluir que apesar de existir divergência morfológica entre os acessos cultivados de $S$. melongena e as formas insanum, não há razão genética para separá-las taxonomicamente.

Além dos já mencionados, diversos outros trabalhos com diferentes espécies podem ser consultados, como: Plekhanova \& Rostova (1994) trabalhando com o gênero Lonicera sp.; Esquivel et al. (1994) com espécies do gênero Arachis sp.; Clements \& Cowling (1994) com Lupinius angustifolius; Spooner et al.(1992) com espécies do gênero Solanum sp; Gizlice et al. (1993) com a geração $F_{2}$ de um cruzamento de soja; Loiselle et al. (1989) com $S$. tuberosum, visando seleção para batata a ser consumida frita; e Stanton et al. (1994) com diferente espécies do gênero Gossypium.

\subsection{Análise dialélica}

Dentro de um programa de melhoramento, envolvendo hibridações, uma das etapas mais importantes é a seleção de acessos a serem utilizados como genitores. Para tanto, tem-se que obter estimativas de parâmetros genéticos, que possibilitem inferências sobre a concentração de alelos 
favoráveis, nos diferentes acessos, bem como analisar as combinações hibridas mais promissoras. Os cruzamentos dialélicos são muito utilizados nesta fase do programa de melhoramento, por fornecerem tais estimativas.

A expressão cruzamento dialélico refere-se a todas as possibilidades de hibridações, feitas aos pares, dentro de um conjunto de genitores (Vega O., 1988). O conceito de cruzamento dialélico foi apresentado por Griffing (1956) como o conjunto das $p^{2}$ combinações híbridas possíveis de serem obtidas a partir de $p$ genitores. De acordo com Hallauer \& Miranda Filho (1988), os esquemas e as análises de cruzamentos dialélicos têm sido desenvolvidos com genitores cujas bases genéticas variam desde linhagens puras, com base estreita, até variedades com ampla base genética.

Segundo Kempthorne (1956), por meio de estudos utilizando cruzamentos dialélicos, o geneticista pode obter melhor entendimento da natureza da ação dos genes envolvidos em caracteres de importância para a agricultura. Do ponto de vista aplicado, os cruzamentos dialélicos fornecem estimativas da capacidade geral de combinação (CGC) e da capacidade específica de combinação (CEC). A CGC caracteriza o comportamento médio de um genitor em uma série de combinações híbridas. Por outro lado, a CEC caracteriza o comportamento de combinações hibridas específicas em relação à média dos genitores (Sprague \& Tatum, 1942). Estes autores diferenciaram os tipos de capacidade combinatória em relação ao tipo de ação gênica predominante. Assim, a CGC está associada principalmente a genes de efeitos aditivos, além de dominantes e epistáticos do tipo aditivo; já a CEC depende basicamente de genes de efeitos dominantes e epistáticos do tipo dominante.

O conhecimento da ação gênica predominante envolvida na expressão de um caráter é de importância prática na definição dos objetivos e dos métodos empregados em um programa de melhoramento. A ação gênica do tipo aditiva está relacionada aos efeitos dos genes, per se, na expressão de um caráter, ao passo que a ação dominante refere-se aos efeitos da interação 
de alelos de um mesmo loco gênico na expressão de um caráter; a epistasia refere-se à interação de genes de locos diferentes na expressão de um caráter.

A ação aditiva depende somente dos alelos de cada gene (unidade básica de herança), sendo, portanto, a fração prontamente herdável da expressão de um caráter, enquanto as interações dominantes e epistáticas dependem da associação de diferentes alelos e de diferentes genes para a sua expressão. Assim, quando a ação aditiva é predominante na expressão de um caráter, recomenda-se o melhoramento intrapopulacional, com o conseqüente desenvolvimento de variedades, linhagens, que poderão ser utilizadas para obtenção de híbridos. No entanto, quando predomina a ação dominante, a estratégia recomendada para explorá-la é a produção de híbridos (Hallauer \& Miranda Filho, 1988).

Além dos parâmetros citados é possivel estimar a heterose existente entre hibridos e genitores, que está associada à diferença de freqüência gênica entre os genitores e ao efeito de dominância do caráter (Hallauer \& Miranda Filho, 1988).

Do ponto de vista genético-estatístico, os cruzamentos dialélicos podem ser analisados segundo os modelos fixo e aleatório. No modelo fixo, os genitores são deliberadamente escolhidos e não podem ser considerados como uma amostra de uma população. A unidade amostral sob análise constitui a própria população, e as conclusões em termos de efeitos de CGC e CEC se referem apenas a estes genitores. Os objetivos são as comparações dos efeitos da capacidade de combinação dos genitores e a identificação das combinações de mais alta produtividade.

No modelo aleatório, os genitores são amostras de uma população de referência e as conclusões são feitas em relação aos parâmetros da população. O principal interesse é estimar os componentes da variância fenotípica (aditiva, dominante e ambiental) envolvidos na expressão dos caracteres analisados (Hallauer \& Miranda Filho, 1988). Para isto, deve-se supor que os efeitos no modelo tenham distribuição normal e que sejam 
independentes, com média zero e variância conhecida. Este modelo é basicamente aplicado para populações segregantes.

Em programas de melhoramento, o conhecimento dos componentes da capacidade combinatória é de relevante importância na escolha de genitores divergentes envolvidos em esquemas de cruzamento, sobretudo quando se deseja identificar híbridos promissores e desenvolver linhagens superiores (Melo, 1987).

Em função do grande interesse pelo tema cruzamentos dialélicos, o conhecimento dos princípios destes evoluíram consideravelmente, podendo-se dispor, no presente, de vários métodos de análise dialélica. Dentre as diferentes metodologias mais comumente utilizadas, Cruz \& Regazzi (1994) destacaram a proposta por Hayman (1954a,b), que fornece informações a respeito do mecanismo básico de herança do caráter em estudo, bem como dos valores genéticos dos genitores e do limite de seleção; o método de Griffing (1956) estima os efeitos da capacidade geral e específica de combinação, enquanto o método de Gardner \& Ebehart (1966) separa a heterose nos seus diversos componentes.

Segundo Cruz \& Regazzi, (1994) existem cinco tipos de cruzamentos dialélicos:

- Dialelos completos ou de meia tabela: podem envolver além da análise de todos os híbridos $F_{1}$ 's, os genitores, os hibridos reciprocos e também a geração $F_{2}$.

- Dialelos parciais: envolvem a análise dos genitores, divididos em dois grupos, e dos híbridos entre genitores de grupos diferentes.

- Dialelos circulantes: os genitores podem ou não ser analisados e cada genitor é representado em $\mathbf{s}$ combinações hibridas, onde $\mathbf{s}$ é menor que o número de combinações necessárias para os dialelos completos.

- Dialelos incompletos: os genitores são representados por número variável de combinações hibridas. 
- Dialelos desbalanceados: são dialelos que possuem número desigual de repetição para os tratamentos.

Dentre os cruzamentos dialélicos, os circulantes apresentam as seguintes vantagens: exigem menor número de hibridações por genitor que os dialelos completos, possibilitando analisar maior número de genitores sem aumento expressivo nos recursos envolvidos; e permitem seleção entre os cruzamentos, de uma amplitude maior de genitores (Kempthorne \& Curnow, 1961). Para determinação dos cruzamentos a serem feitos para avaliar os genitores no esquema de dialelo circulante, estes autores desenvolveram um algoritmo, de modo a garantir que os cruzamentos selecionados sejam amostras dos possíveis cruzamentos a serem feitos com cada genitor.

Em relação à confiabilidade das estimativas dos parâmetros genéticos obtidos com dialelos circulantes, Dhillon \& Singh (1978) concluíram que $\circ$ grau de precisão destas estimativas varia de acordo com o número de cruzamentos por genitor, sendo, porém, menor que a precisão obtida nos dialelos completos, em função do menor número de combinações híbridas por genitor. No entanto, Veiga (1998), ao avaliar a eficiência dos dialelos circulantes por meio de simulação, observou que as correlações entre as estimativas obtidas com o dialelo circulante e com as do dialelo completo, foram significativas, mesmo para número pequeno de combinações por genitor, o que evidencia a eficiência dos dialelos circulantes como alternativa na escolha de genitores para um programa de melhoramento.

Oliveira Júnior (1995) comparou a eficiência do dialelo circulante desbalanceado com outros dialelos também desbalanceados e concluiu que o primeiro foi mais eficiente, por ter fornecido informações da CGC para sete genitores com sete hibridações; para os demais dialelos, seis hibridações foram necessárias para estimar a CGC de apenas quatro genitores. Neste sentido, Dantas (1988) e Gonçalves (1987), trabalhando com milho, concluíram que os dialelos circulantes são eficientes, por permitirem a obtenção das estimativas de parâmetros genéticos a partir de pequeno número de genitores. 
Diversas metodologias de análise dialélica têm sido empregadas em programas de melhoramento de berinjela, com diferentes objetivos. Assim Chadha et al. (1988) analisaram nove genitores de berinjela no que se refere a caracteres relacionados à coloração do fruto, utilizando-se de cruzamento dialélico completo, no período de 1978 a 1980. Concluíram que o cultivar 'Pusa Kranti" (PK), foi o que apresentou a maior capacidade geral de combinação para os caracteres concentração de clorofila total, clorofila $a$, clorofila b e concentração de antocianina na casca dos frutos. O cruzamento de PK com "Pusa Purple Long" (PPL) mostrou a maior capacidade especifica de combinação com relação aos caracteres de coloração de frutos.

Trabalhando com cruzamento dialélico de cinco genitores de berinjela com frutos compridos, Singh \& Kumar (1988) concluíram que as variedades "Aru1" e "Sel 5" foram as que apresentaram a maior capacidade geral de combinação para produção de frutos. O cruzamento "Grupo" x "Sel 5" apresentou a maior capacidade específica de combinação e heterose de $162,5 \%$ em relação ao genitor superior.

Chadha \& Hegde (1989), trabalhando com cruzamento dialélico de nove linhagens de berinjela e seus híbridos, sem análise de reciprocos, concluíram que o cruzamento do genitor com maior capacidade geral de combinação com o mais divergente em relação a este foi o que apresentou o maior efeito heterótico.

Narendra \& Ram (1989), analisando um cruzamento dialélico de seis genitores e seus híbridos, sem análise de recíprocos, concluíram que ambos os componentes aditivos e não-aditivos foram importantes para os caracteres altura de planta, número de frutos/planta e peso de fruto. A herdabilidade foi moderada para número de ramificações/planta e número de frutos/planta e baixa para produção.

Verma et al. (1986) verificaram que a heterose em relação ao genitor superior foi significativa para sete caracteres, sendo detectada em um cruzamento dialélico de berinjela. O híbrido "Punjab Bahar" $X$ "Pusa Purple 
Long" apresentou heterose de $13 \%$ em relação ao genitor superior, sendo, portanto recomendado seu estudo para obtenção de futuras linhagens e utilização como hibrido comercial.

Em Kanpur (Índia), Singh \& Mital (1988), analisando o cruzamento dialélico de 12 genitores divergentes de berinjela e seus hibridos, sem recíprocos, concluíram que os caracteres dias para florescimento, altura de planta e produção por planta são controlados por ação gênica não-aditiva. Os autores recomendaram trabalhar com seleção recorrente, para melhorar a população básica obtida do intercruzamento deste material.

Rashid et al. (1988), trabalhando com estimativas de variabilidade genética e capacidade de combinação em berinjela, mediante análise dialélica, utilizando meia tabela, do cruzamento de cinco genitores, concluíram que as variâncias para capacidade geral e específica de combinação foram significativas a $5 \%$ de probabilidade. A variedade "Pusa Purple Long" apresentou a maior capacidade geral de combinação para produção. No cruzamento "Pusa Purple Long" $X$ "Islampuri", esses autores observaram que a heterose foi significativa em relação ao genitor superior.

Awasthi et al. (1987) avaliaram um cruzamento dialélico completo entre 16 cultivares de berinjela do tipo fruto longo, que foram analisados com relação a propriedades organolépticas e produção. A capacidade geral de combinação para caracteres culinários foi máxima no cultivar "NDB25" e, para produção de frutos, no cultivar "NDB2". Os autores sugeriram um programa de melhoramento envolvendo o cruzamento biparental destes dois cultivares, objetivando a obtenção de linhagens com bom potencial produtivo e com características culinárias desejáveis.

Embora muitas análises dialélicas demonstrem a importância dos efeitos gênicos não-aditivos para produção em berinjela, Verma et al. (1986), trabalhando com dialelo, meia tabela, de seis cultivares de S. melongena, concluíram que, para sete caracteres relacionados à produção, os efeitos de 
capacidade geral de combinação foram significativamente maiores que a capacidade específica.

Patel et al. (1994), utilizando um dialelo completo em berinjela com sete variedades, sem recíprocos, concluíram que, a ação gênica do tipo nãoaditiva foi predominante no controle de sete caracteres relacionados à produção de frutos. Entretanto, Ingale \& Patil (1997) analisando um dialelo completo sem recíprocos, com dez genitores, concluíram que a ação aditiva dos genes foi predominante para os caracteres: precocidade, produção de frutos e número de frutos por planta. Padmanabham \& Jagadish (1996), trabalhando com cruzamento dialélico de oito variedades de berinjela, concluíram que a ação gênica aditiva é predominante na expressão dos componentes primários da produção de frutos. Não foi encontrado nenhum relato, na literatura analisada, sobre a utilização de dialelo circulante em berinjela.

\subsection{Associação entre divergência genética de genitores e comportamento de híbridos}

A divergência genética existente dentro de um grupo de acessos é associada às diferenças nas freqüências alélicas existentes entre os materiais sob análise. Por outro lado, a heterose é também função das diferenças nas freqüências alélicas existentes entre os genitores, sendo associada ao efeito de dominância dos caracteres (Falconer \& Mackay, 1996). Cruz \& Vencovsky (1989), comparando alguns métodos de análise dialélica, concluíram que as estimativas de CEC ( $s_{i i}$ e $s_{i j}$ ) estão diretamente associadas à divergência genética; dessa forma, a variação nas freqüências alélicas é o elemento comum entre divergência genética, heterose e CEC.

Diversos trabalhos científicos têm demonstrado a associação entre medidas de divergência genética e parâmetros genéticos estimados em análise dialélica. Ghaderi et al. (1984), trabalhando com feijão (Phaseolus vulgaris L.) e fava (Vicia faba L.), concluíram que existe associação positiva entre a 
divergência observada entre os genitores, a heterose e a CEC detectada nos híbridos.

Cruz et al. (1994a), trabalhando com características biométricas em milho ( $Z$. mays L.), concluíram que a associação, mediante o uso de medidas de correlação, entre divergência genética dos genitores e o desempenho dos híbridos era significativamente positiva e que, portanto, existe satisfatória eficiência da predição do comportamento de híbridos de milho a partir da divergência genética de seus genitores. Respostas similares foram obtidas por Ferreira (1993), também trabalhando com milho; Dias \& Kageyama (1997b) com cacau ( $T$. cacao L), Carvalho (1993) com algodão (G. hirsutum L. ) e Amaral Júnior (1996) com tomate.

A associação de estimativas da divergência genética, a partir de dados moleculares, com desempenho de hibridos também tem sido investigada. Neste sentido, Saghai Maroof et al. (1997), estudando a associação entre a divergência estimada entre acessos de arroz (Oriza sativa L.), a partir de polimorfismos de "RFLP" (restriction fragment lenght polymorphisms), e a heterose de híbridos destes acessos, analisados em um cruzamento dialélico, concluíram que a associação entre divergência e heterose é significativa para características relacionadas à produção de grãos. Resultados similares foram relatados em soja (Manjarrez-Sandoval et al., 1997) e em Brassica napus L. (Diers et al., 1996). 


\section{Cap. I: ESTABILIDADE DA DIVERGÊNCIA GENÉTICA ENTRE ACESSOS DE BERINJELA EM TRÊS ESTÁDIOS DO DESENVOLVIMENTO}

\subsection{Introdução}

O grande interesse pelo tema divergência genética surge devido ao fato de ser possivel demonstrar que a média dos valores fenotípicos expressa, em maior ou menor grau, o valor genotípico do individuo. Dessa forma, ao se avaliar a divergência entre populações, com base em dados fenotípicos médios, está se avaliando a divergência entre valores genotípicos, a qual está associada à diferença de freqüência gênica entre as diferentes unidades amostrais (acessos, populações, variedades e clones).

Segundo Falconer \& Mackay (1996), a magnitude da heterose manifestada num cruzamento entre duas unidades amostrais depende do quadrado da diferença de freqüência gênica entre estas, multiplicado pelo desvio de dominância do caráter sob análise. Dessa forma, associa-se divergência genética com heterose (Cress, 1966), o que aumenta o interesse por esse tema.

A divergência genética entre acessos é também de grande importância para programas de melhoramento, pois, para que o processo seletivo durante as diferentes fases do programa tenha sucesso, é necessário que a base genética seja ampla nas primeiras gerações após a hibridação (Hallauer \& Miranda Filho, 1988). 
Nas avaliações dos recursos genéticos existentes nos bancos de germoplasma, as análises de divergência são também muito empregadas na caraterização dos acessos, bem como na eliminação de acessos duplicados, contribuindo dessa maneira para a redução dos custos de manutenção das coleções. Atualmente, diversos autores têm publicado estratégias para se manter coleções nucleares (Berthaud, 1997; Holbrook et al., 1993; Spagnoletti Zeulli \& Qualset, 1993), visando reduzir os custos e facilitar o manuseio dos acessos das coleções mediante o uso da divergência genética.

Dentre as diversas técnicas utilizadas para expressar a divergência em termos genéticos entre unidades amostrais, cita-se a distância generalizada de Mahalanobis $\left(D^{2}\right)$, que é considerada uma das mais consistentes (Rao, 1952). A partir da estimação de $D^{2}$ faz-se a análise de agrupamento, que, segundo Bussab et al. (1990), envolve várias técnicas e algoritmos, cujo objetivo é reunir objetos e indivíduos semelhantes em grupos.

$\mathrm{O}$ processo de agrupamento envolve duas etapas. A primeira relaciona-se com a estimação da divergência entre os indivíduos e a segunda com a técnica de formação de grupos, que é feita de modo a se obter alto grau de homogeneidade dentro de cada grupo e heterogeneidade entre estes (Johnson \& Wichern, 1982). De acordo com Cruz \& Regazzi (1994), o algoritmo de Tocher é muito utilizado como critério de agrupamento.

A interpretação das análises de divergência genética e dos métodos de agrupamento muitas vezes torna-se difícil, em decorrência da nãorepetibilidade dos valores de divergência, os quais podem variar em função do número de caracteres analisados (Arunachalan, 1981; Cruz et al., 1994a), da interação genótipo ambiente (Camussi et al., 1985; Murty et al., 1973; Naidu \& Satyanarayana, 1991; Singh \& Gill, 1984;), bem como de variações ao longo dos anos de cultivo (Dias \& Kageyama, 1997a). Neste sentido, Viana et al. (1991), trabalhando com cana-de-açúcar, encontraram variação na composição e no número de grupos formados entre cortes diferentes. 
Assim, buscou-se estudar a estabilidade da divergência genética entre acessos de berinjela, estimada em diferentes estádios do desenvolvimento da planta. Para tanto, os objetivos do presente trabalho foram: estimar a divergência genética entre acessos de berinjela em três estádios do desenvolvimento da planta; e analisar a estabilidade existente entre a diversidade estimada entre acessos, nos diferentes estádios de desenvolvimento estudados.

\subsection{Material e métodos}

\subsubsection{Material vegetal}

Foram avaliados 17 acessos de berinjela (S. melongena L.) do banco de germoplasma de hortaliças do Departamento de Genética da ESALQ/USP (Tabela 1) e dois híbridos ('Nápoli' e 'Super F 100') comercializados no Brasil.

\subsubsection{Avaliação de Campo}

O presente trabalho foi conduzido no periodo de agosto de 1996 a janeiro de 1997, na área experimental do Departamento de Genética da ESALQ/USP, em Piracicaba - SP, que se localiza a $22^{\circ} 43^{\prime}$ de latitude, $47^{\circ}$ $38^{\prime}$ de longitude, com temperatura média máxima de $28,1^{\circ}$ e média mínima de $14,6^{\circ}$ (média de 30 anos) E precipitação de 1202,7 mm/ano (média de 30 anos).

O experimento foi conduzido no delineamento em blocos ao acaso com três repetições, e parcelas de oito plantas. As quatro plantas centrais constituíram a área útil. Os tratos culturais foram os recomendados por Filgueira (1982). 
Tabela 1. Acessos de berinjela do banco de germoplasma de hortaliças do Departamento de Genética da ESALQ/USP e híbridos comerciais, país de origem $e$ instituição que cedeu os acessos $e$ as observações sobre os mesmos. ESALQ/USP, Piracicaba, SP.

\begin{tabular}{clll}
\hline Código & Designação & Origem: país-instituição & Observações \\
\hline L1 & PI 206472 & Turquia-USDA & \\
L2 & 'Long Green' & GUAM-USDA & Resistente à antracnose \\
L3 & 'Campineira' & BRASIL-IAC & \\
L4 & 'Florida Market' & BRASIL-IAC & \\
L5 & 'E 22' & TAIWAN-USDA & Resistente à antracnose \\
L6 & PI 169667 & TURQUIA-USDA & \\
L7 & PI 210026 & INDIA-USDA & \\
L8 & PI 224690 & BURMA-USDA & \\
L9 & PI 269953 & INDIA-USDA & \\
L10 & PI 166995 & TURQUIA-USDA & \\
L11 & 'Annamalai Brinjal' & INDIA-USDA & \\
L12 & 'Indiana' & EUA-USDA & \\
L13 & PI 319855 & THAILÂNDIA-USDA & \\
L14 & Sel ESALQ 1* & BRASIL-ESALQ & \\
L15 & Sel ESALQ 2 & BRASIL-ESALQ & \\
L16 & Sel ESALQ 3 & BRASIL-ESALQ & \\
L17 & PI 176760 & TURQUIA-USDA & \\
H1 & 'Nápoli' & BRASIL & Híbrido comercial \\
H2 & 'Super F100' & BRASIL & Hibrido comercial \\
\hline
\end{tabular}

${ }^{1}$ A letra $\mathrm{H}$ designa os híbridos.

${ }^{2}$ A letra $L$ designa os acessos.

* Sel ESALQ = Seleção ESALQ. 
Os acessos foram avaliados em relação a 29 caracteres, com base na lista de descritores de berinjela (IBPGR, 1990), e agrupados em três conjuntos, segundo o estádio de desenvolvimento:

\subsubsection{Caracteres vegetativos}

- Número de dias para a emergência (NDE): foi obtido contando-se os dias da semeadura até a emergência de $50 \%$ das plântulas.

- Comprimento médio do cotilédone (CMC), expresso em milímetro (mm): utilizando-se régua flexivel, mediu-se o comprimento longitudinal de dez folhas cotiledonares, totalmente expandidas, por repetição e, posteriormente, calculou-se o comprimento médio destas.

- Largura média do cotilédone (LMC), expressa em mm: foi obtida utilizando-se a mesma metodologia descrita para o item anterior, porém medindo-se transversalmente as folhas cotiledonares na parte central destas.

- Comprimento médio do hipocótilo (CMH), expresso em mm: foi obtido a partir do comprimento do hipocótilo de quatro plântulas, por repetição, 20 dias pós emergência.

- Comprimento médio da radícula (CMR), expresso em mm: foi obtido a partir do comprimento médio da radícula de quatro plântulas, por parcela, no mesmo estádio do desenvolvimento descrito anteriormente.

Todos os demais caracteres deste estádio foram medidos aos 70 (setenta) dias pós-transplantio.

- Diâmetro médio do caule (DMC), expresso em mm: foi medido o diâmetro do caule, na região mediana do quinto entrenó a partir do solo, das quatro plantas da área útil da parcela, utilizando-se paquímetro graduado em décimos de milímetro $(0,1 \mathrm{~mm})$. 
- Comprimento médio de entrenó (CME), expresso em mm: foi obtido de maneira similar ao item anterior, porém medindo-se longitudinalmente o quinto entrenó, a partir do solo, utilizando-se régua flexível graduada em $\mathrm{mm}$.

- Comprimento médio do limbo foliar (CMLF), expresso em centímetro $(\mathrm{cm})$ : mediu-se o comprimento da nervura central da primeira folha totalmente expandida, a partir do ápice, em cada uma das quatro plantas da área útil da parcela.

- Largura média do limbo foliar (LMLF), expressa em cm: obtido de maneira similar ao item anterior, porém medindo-se transversalmente as folhas, na região de maior diâmetro.

- Comprimento médio do peciolo (CMP), expresso em cm: utilizando-se as folhas descritas para o item CMLF, mediu-se comprimento do pecíolo destas.

- Número médio de folhas (NMF): foi obtido a partir do número de folhas, totalmente expandidas das quatro plantas da área útil da parcela.

- Altura média de planta (AMP), expressa em $\mathrm{cm}$ : foi obtida medindo-se o caule, do solo à gema apical, das quatro plantas da área útil da parcela e calculando-se a média aritmética dos quatro valores.

\subsubsection{Caracteres reprodutivos}

- Número médio de dias para o florescimento (NMDF): obtido a partir do número de dias necessários para a abertura da primeira flor em cada uma das quatro plantas da área útil da parcela.

- Número médio de botões/inflorescência (NMBI): aos 110 dia póstransplantio, contou-se o número de botões de quatro inflorescências de cada uma das quatro plantas da área útil da parcela. Após isto, calculou-se a média do número de botões florais por planta e o número médio de botões por inflorescência. 
- Número médio de flores/inflorescência (NMFI): obtido com a mesma metodologia descrita para o item anterior, porém contando-se o número de flores abertas em cada inflorescência.

- Número médio de frutos/inflorescência (NMFRI): utilizando a metodologia descrita no item NMBI, contou-se o número de frutos com diâmetro igual ao superior a 2 centímetros $(\mathrm{cm})$.

- Número médio de pétalas (NMP): foi obtido contando-se o número de pétalas de duas flores totalmente abertas de cada uma das quatro plantas da área útil da parcela; posteriormente, calculou-se a média do número de pétalas por planta e, a partir deste, o número médio de pétalas por flor.

- Número médio de sépalas (NMS): foi obtido utilizando-se a mesma metodologia descrita para o item NMP, porém contando-se o número de sépalas.

- Comprimento médio do pedúnculo (CMP), expresso cm: foi obtido a partir do comprimento de dez pedúnculos de frutos colhidos por parcela.

- Diâmetro médio do pedúnculo (DMP), expresso em $\mathrm{mm}$ : utilizando-se paquimetro e o material vegetal descrito no item CMP, mediu-se o diâmetro dos pedúnculos a 1 (um) centímetro da extremidade distal (região de conexão entre pedúnculo e fruto) destes.

- Peso do pedúnculo (PP), expresso em gramas (g): foi obtido pesando-se o material vegetal descrito no item CMP, em balança de precisão.

- Diâmetro médio do cálice (DMCA), expresso em mm: utilizandose paquímetro, mediu-se o diâmetro de dez cálices e posteriormente, fez-se o cálculo da média aritmética. Os cálices utilizados foram escolhidos ao acaso, dentre os cálices aderidos aos frutos colhidos nas quatro plantas da área útil da parcela.

- Peso do cálice (PC), expresso em gramas (g): o material vegetal descrito no item anterior foi pesado em balança de precisão. 
- Comprimento médio das sépalas (CMS), expresso em $\mathrm{mm}$ : foi obtido utilizando-se o material vegetal descrito no item DMCA, de onde foram destacadas e medidas as sépalas, da extremidade ao ponto de inserção no cálice.

\subsubsection{Caracteres produtivos}

Foram feitas seis colheitas, tendo sido avaliados os seguintes caracteres, quando os frutos estavam no ponto de colheita comercial:

- Comprimento médio de fruto (CMF), expresso em cm: foi obtido medindo-se o comprimento médio de dez frutos, no sentido longitudinal, por parcela, em cada colheita. Posteriormente, calculou-se a média do comprimento de fruto a partir das estimativas dos comprimentos médios dos frutos obtidos em cada colheita. Este método foi utilizado para os caracteres DMF e PMF.

- Diâmetro médio de fruto (DMF), expresso em $\mathrm{cm}$ : foi obtido medindo-se dez frutos transversalmente, na parte de maior diâmetro dos frutos, por colheita.

- Peso médio de fruto (PMF), expresso em gramas por fruto (g/fruto): foi obtido pela pesagem de dez frutos, por colheita, em balança com precisão de um grama, com posterior cálculo da média aritmética.

- Número médio de frutos por planta (NMFP): somaram-se todos os frutos com padrão comercial colhidos em cada parcela e, posteriormente, dividiu-se por quatro (número de plantas da área útil da parcela).

- Produção total de frutos/planta (PROD), expressa em gramas por planta (g/planta): foi obtida pela soma das pesagens de todos os frutos, com padrão comercial colhidos em cada parcela; posteriormente, dividiu-se por quatro (número de plantas da área útil da parcela). 


\subsubsection{Análise estatistica}

Foi feita análise de variância multivariada dos dados utilizando-se a estatística $\Lambda$ de Wilks (Pimentel Gomes, 1990) assim definida:

$$
\Lambda=\frac{\operatorname{det} E}{\operatorname{det} A},
$$

em que

det $E$ - determinante da matriz de somas de quadrados e produtos do resíduo;

det $\mathrm{A}$ - determinante da matriz de somas de quadrados e produtos de tratamentos mais soma de quadrados e produtos do resíduo (Pimentel Gomes, 1990).

$O$ valor de $\Lambda$ foi utilizado para o teste de significância das diferenças entre vetores de média de tratamentos, transformados nos correspondentes valores de F (Harris, 1975), cuja expressão é:

$$
F\left[\mathrm{pk}_{1}, a b-c\right]=\left[\left(\frac{1}{\Lambda}\right)^{\frac{1}{b}}-1\right] \frac{\mathrm{ab}-\mathrm{c}}{\mathrm{pk}_{1}}
$$

em que

$$
\begin{aligned}
& a=k_{2}-0,5\left(p-k_{1}+1\right) \\
& b=\sqrt{\frac{p^{2} k_{1}^{2}-4}{p^{2}+k_{1}^{2}-5}}, \text { no caso de } p^{2}+k_{1}^{2} \neq 5 ; \\
& c=0,5\left(p k_{1}-2\right) ; \\
& p: \text { número de caracteres; } \\
& K_{1}: \text { número de graus de liberdade para tratamento; e } \\
& K_{2}: \text { número de graus de liberdade do resíduo. }
\end{aligned}
$$

Os dados foram submetidos ao teste de normalidade de Kolmogorov - Smirnov (Steel et al., 1997), usando o programa Sigma-Stat. Os 
dados dos caracteres número médio de folhas (NMF), número médio de flores/inflorescência (NMFI) e número médio de fruto/inflorescência (NMFRI), foram transformados, em função desta análise, para $\sqrt{\mathrm{NMF}}, \sqrt{\mathrm{NMFI}} e$

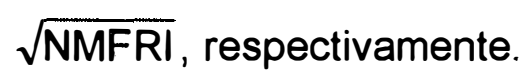

A divergência genética entre acessos (Rao, 1952) foi estimada pela distância generalizada de Mahalanobis $\left(D_{i i^{\prime}}^{2}\right)$, definida como:

$$
\mathrm{D}_{\mathrm{ii}}^{2}=d^{\prime} \mathrm{W}^{-1} \underset{\sim}{d}
$$

em que

$\underset{\sim}{d}$ : vetor de diferenças entre médias dos acessos para todos os $p$ caracteres;

$d_{\sim}^{\prime}$ ': seu transposto; e

W: matriz $p \times p$ de variâncias e covariâncias residuais.

Para evitar a inversão da matriz $W$, a qual, quando de ordem elevada, proporciona erros numéricos grandes (Cruz \& Regazzi, 1994), podese utilizar o processo de condensação pivotal, que consiste em se justapor à direita da matriz W a matriz-identidade. Após isto, por operações elementares nas linhas de $W$, busca-se obter uma matriz diagonal superior (Searle, 1971), com todos os elementos da diagonal iguais a 1 (um). A seqüência de elementos nas linhas da matriz justaposta à direita, após cada condensação, corresponde aos coeficientes de transformação linear das variáveis originais em variáveis não-correlacionadas; o elemento da diagonal da matriz da esquerda corresponde à variância desta variável (Rao, 1952).

O processo de condensação pivotal fornece a combinação para a transformação do conjunto de variáveis correlacionadas $X_{j}$ em variáveis independentes $Z_{j}$ (Cruz \& Regazzi, 1994).

Assim, a distância generalizada de Mahalanobis pode ser obtida pelo estimador: 


$$
D_{i i^{\prime}}^{2}=\sum_{j=1}^{n}\left(Z_{i j}-Z_{i^{\prime} j}\right)^{2}
$$

em que

$$
\begin{aligned}
& D_{i i^{\prime}}^{2} \text { : distância generalizada de Mahalanobis entre os acessos i i'; e } \\
& Z_{\mathrm{ij}} \text { : } \text { média da j-ésima variável transformada pelo processo de } \\
& \text { condensação pivotal. As variáveis } Z \text { têm variâncias residuais } \\
& \text { iguais a um e são não-correlacionadas. }
\end{aligned}
$$

Para a delimitação dos grupos de similaridade, adotou-se a técnica conglomerativa de Tocher, conforme recomendado por Rao (1952). Por este método, a média das medidas de dissimilaridade dentro de cada grupo deve ser menor que as distâncias médias entre quaisquer grupos. O método consiste inicialmente na identificação do par de acessos cuja estimativa de $D^{2}$ seja a menor dentre as estimativas obtidas na matriz de dissimilaridade entre acessos. A partir deste primeiro par de acessos, faz-se a avaliação da possibilidade de inclusão de novos acessos neste grupo, segundo algum critério de classificação. Para este trabalho, o critério adotado foi o de que a dissimilaridade dentro do grupo deve ser menor que o maior valor encontrado, no conjunto das menores distâncias, envolvendo cada acesso.

Assim, como a entrada de um acesso em um grupo aumenta o valor da distância média dentro do grupo, pode-se tomar a decisão de incluir ou não um acesso em um grupo por meio da comparação entre o valor médio da distância dentro do grupo com a entrada do novo acesso e o nível máximo permitido pelo critério adotado. Se a distância média dentro do grupo não ultrapassar esse limite, o novo acesso é aceito. Se, porém, com a inclusão ultrapassa-se o limite, a inclusão é rejeitada e reinicia-se o trabalho para formar um novo grupo, porém mantendo sempre o mesmo critério (Cruz \& Regazzi, 1994).

A estimação da distância média entre e dentro de cada grupo foi feita segundo Singh \& Chaudary (1979). A estimação da distância média dentro 
do grupo consiste em se calcular a média das distâncias entre pares de acessos de um mesmo grupo; a distância entre grupos é estimada pela média das distâncias entre todos os pares de acesos dos grupos.

Utilizou-se o critério de Singh (1981), com base nas estimativas de $D^{2}$, para se identificar a contribuição relativa de cada caráter para a diversidade entre os acessos. Este critério baseia-se na partição do total das estimativas de $\mathrm{D}^{2}$, considerando todos os possíveis pares de indivíduos, nas partes devidas a cada caráter.

A correlação de Spearman (Steel et al., 1997) foi estimada entre pares de valores de divergência $\left(D_{i i^{\prime}}^{2}\right)$ obtidos nos diferentes estádios de desenvolvimento para cada par de acesso, cujo estimador é:

$$
\hat{r_{s}}=1-\frac{6 \sum_{i=1}^{n} d_{i}^{2}}{(n-1) n(n+1)},
$$

em que

$d_{i}$ : diferença entre as estimativas de $D_{i i}^{2}$, para cada par de acesso, entre dois estádios do desenvolvimento; e

$\mathrm{n}$ : número de pares de acesso.

Calculou-se o coeficiente de coincidência entre os 20 pares de acessos mais divergentes e os mais similares, estimados nos diferentes estádios de desenvolvimento. Em todas as análises foi utilizado o programa Genes (Cruz, 1997). 


\subsection{Resultados}

\subsubsection{Estádio vegetativo}

A análise multivariada aplicada aos caracteres do estádio vegetativo, com base na estatistica $\Lambda\left(\Lambda=1,94 \times 10^{-4}\right)$ de Wilks, transformada para o correspondente valor de $F(216 ; 279,55)=1,71$ detectou diferenças significativas $(P<0,01)$ entre os acessos em relação aos caracteres analisados simultaneamente.

Em relação à análise de grupos (Tabela 2), observa-se que foram formados apenas dois grupos. $O$ par de acessos mais divergente foi $L 4$ ('Florida Market') e L 10 (PI 166995), com $D^{2}=166,00$ (Tabela 3), enquanto L 5 ('E-22') e L15 (Sel ESALQ 2) foi o par menos divergente, com $D^{2}=3,20$. Os caracteres que menos contribuíram para análise da divergência (Tabela 4) pelo critério de Singh (1981) foram CMR, DMC, CME, NMF e AMP.

\subsubsection{Estádio reprodutivo}

Em relação aos caracteres do estádio reprodutivo, aplicando-se a estatística $\Lambda\left(\Lambda=2,41 \times 10^{-6}\right)$ de Wilks, transformada para o correspondente valor de $F(216 ; 279,55)=3,39$ observou-se diferenças significativas $(P<0,01)$ entre os vetores de médias dos acessos, demonstrando a presença de variabilidade com relação a estes caracteres.

Observou-se ainda que da análise dos dados deste estádio (Tabela 2) foram formados quatro grupos, com distâncias médias inter-grupos (Tabela 5) superiores às obtidas no estádio vegetativo, demonstrando assim maior capacidade de discriminação destes caracteres em relação aos do estádio anterior. Com este conjunto de caracteres, o par de acesso mais divergentes, foi L 4 ('Florida Market') e L 10 (PI166995), com D² = 412,91 (Tabela 6), em 
concordância com o estádio anterior, enquanto o menos divergente foi $L 2$ ('Long green') e L12 ('Indiana'), com $D^{2}=6,19$.

Tabela 2. Grupos de acessos similares de berinjela estabelecidos pelo método de agrupamento de Tocher (Rao, 1952), com base na avaliação dos caracteres dos estádios vegetativo, reprodutivo e produtivo. ESALQ/USP, Piracicaba, SP.

\begin{tabular}{|c|c|c|c|}
\hline \multirow[b]{2}{*}{ Grupo } & \multicolumn{3}{|c|}{ Estádios } \\
\hline & Vegetativo & Reprodutivo & Produtivo \\
\hline 1 & $\begin{array}{l}\text { L 1, L 2, L 3, L 5, L 6, } \\
\mathrm{L} 7, \mathrm{~L} 8, \mathrm{~L} 9, \mathrm{~L} 10, \\
\mathrm{~L} 11, \mathrm{~L} 12, \mathrm{~L} 13, \mathrm{~L} 14, \\
\mathrm{~L} 15, \mathrm{~L} 16, \mathrm{~L} 17, \mathrm{H} 1 \mathrm{e} \\
\mathrm{H} 2 .\end{array}$ & $\begin{array}{l}\text { L 2, L 5, L 11, } \\
\text { L 12, L } 13 .\end{array}$ & L 2, L 12, L 13. \\
\hline II & L 4. & $\begin{array}{l}\text { L 1, L } 3, L 6, \\
\text { L 8, L } 9, L 10, \\
\text { L 14, L 16, H 1, } \\
\text { H2. }\end{array}$ & $\begin{array}{l}\text { L 1, L 3, L 6, L14, } \\
\text { L 15, L 16, H 1, } \\
\text { H2. }\end{array}$ \\
\hline III & & L 7, L17. & $\begin{array}{l}\text { L 7, L 8, L 9, L 11, } \\
\text { L } 17 .\end{array}$ \\
\hline IV & & L 4, L 15. & L 5. \\
\hline V & & & L 10. \\
\hline VI & & & L 4. \\
\hline
\end{tabular}




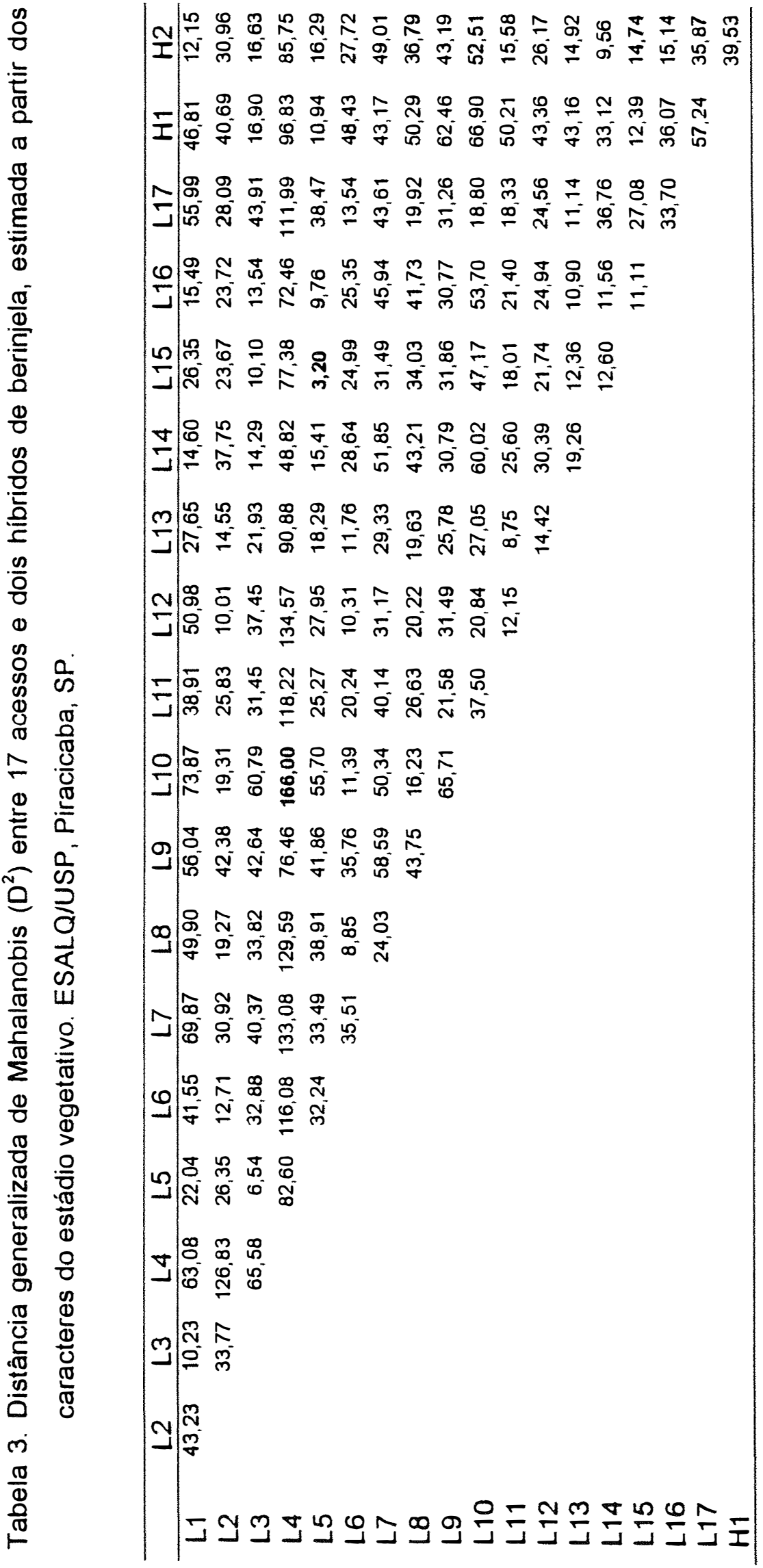


Tabela 4. Contribuição relativa percentual dos caracteres para divergência $\left(D^{2}\right)$, analisada com base no critério de Singh (1981), em três estádios do desenvolvimento de berinjela. ESALQ/USP, Piracicaba, SP.

\begin{tabular}{|c|c|c|c|c|c|}
\hline \multicolumn{6}{|c|}{ Estádios } \\
\hline \multicolumn{2}{|c|}{ Vegetativo } & \multicolumn{2}{|c|}{ Reprodutivo } & \multicolumn{2}{|c|}{ Produtivo } \\
\hline Caráter & $\begin{array}{c}\text { Cont. Rel } \\
(\%)^{\star}\end{array}$ & Caráter & $\begin{array}{c}\text { Cont. Rel } \\
(\%)^{*}\end{array}$ & Caráter & $\begin{array}{c}\text { Cont. Rel } \\
(\%)^{\star}\end{array}$ \\
\hline $\mathrm{NDE}^{-1}$ & 28,55 & $\mathrm{NMDF}^{13}$ & 08,18 & $\mathrm{CMF}^{25}$ & 13,94 \\
\hline $\mathrm{CMC}^{2}$ & 07,26 & $\mathrm{NMBI}^{14}$ & 12,45 & $\mathrm{DMF}^{26}$ & 45,65 \\
\hline $\mathrm{LMC}^{3}$ & 09,56 & $\mathrm{NMFI}^{15}$ & 02,09 & $\mathrm{PMF}^{27}$ & 06,65 \\
\hline $\mathrm{CMH}^{4}$ & 08,64 & NMFRI $^{16}$ & 01,10 & NMFP ${ }^{28}$ & 30,85 \\
\hline $\mathrm{CMR}^{5}$ & 01,84 & NMP $^{17}$ & 02,56 & PROD $^{29}$ & 02,91 \\
\hline$D C^{6}$ & 00,36 & $\mathrm{NMS}^{18}$ & 08,28 & & \\
\hline $\mathrm{CME}^{7}$ & 05,03 & $\mathrm{CMP}^{19}$ & 00,65 & & \\
\hline $\mathrm{CMLF}^{8}$ & 13,06 & $\mathrm{DMP}^{20}$ & 07,58 & & \\
\hline $\operatorname{LMLF}^{9}$ & 08,95 & $P P^{21}$ & 18,61 & & \\
\hline $\mathrm{CMP}^{10}$ & 10,70 & $\mathrm{DMCA}^{22}$ & 19,39 & & \\
\hline $\mathrm{NMF}^{11}$ & 02,48 & $P C^{23}$ & 01,76 & & \\
\hline AMP $^{12}$ & 03,57 & $\mathrm{CMS}^{24}$ & 17,35 & & \\
\hline
\end{tabular}

${ }^{*}$ Contribuição relativa.

1 NDE: número de dias para emergência, ${ }^{2} \mathrm{CMC}$ : comprimento médio dos cotilédones, ${ }^{3}$ LMC: largura média dos cotilédones, ${ }^{4} \mathrm{CMH}$ : comprimento médio do hipocótilo, ${ }^{5}$ CMR: comprimento médio da radícula, ${ }^{6} \mathrm{CMC}$ : comprimento médio do caule, ${ }^{7} \mathrm{CME}$ : comprimento médio do entrenó, ${ }^{8} \mathrm{CMLF}$ : comprimento médio do limbo foliar, ${ }^{9}$ LMLF: largura média do limbo foliar, ${ }^{10}$ CMP: comprimento médio do pecíolo, ${ }^{11}$ NMF: número médio de folhas, ${ }^{12}$ AMP: altura média de planta, ${ }^{13}$ NMDF: número médio de dias para o florescimento, ${ }^{14} \mathrm{NMBI}$ : número médio de botões/ inflorescência, ${ }^{15} \mathrm{NMFI}$ : número médio de flores/ inflorescência, ${ }^{16}$ NMFRI: número de médio de frutos/ inflorescência, ${ }^{17}$ NMP: número médio de pétalas, ${ }^{18}$ NMS: número médio de sépalas, ${ }^{19} \mathrm{CMP}$ : comprimento médio do pedúnculo, ${ }^{20}$ DMP: diâmetro médio do pedúnculo, ${ }^{21}$ PP: peso do pedúnculo, ${ }^{22}$ DMCA: diâmetro médio do cálice, ${ }^{23} \mathrm{PC}$ : peso do cálice, ${ }^{24} \mathrm{CMS}$ : comprimento médio das sépalas, ${ }^{25} \mathrm{CMF}$ : comprimento médio de fruto, ${ }^{26}$ DMF: diâmetro médio de fruto, ${ }^{27}$ PMF: peso médio de fruto, ${ }^{28}$ NMFRC: número médio de frutos comerciais, ${ }^{29}$ PROD: produção total de frutos/planta. 
Tabela 5. Distância $\left(D^{2}\right)$ intra e inter-grupo entre acessos de berinjela, avaliados em relação aos caracteres dos estádios vegetativo, reprodutivo e produtivo. ESALQ/USP, Piracicaba, SP.

\begin{tabular}{|c|c|c|c|c|c|c|}
\hline Grupo & 1 & II & III & IV & V & VI \\
\hline 1 & $\begin{array}{l}30,30 \\
\text { b } 34,44 \\
\text { c } 3,45\end{array}$ & $\begin{array}{l}99,78 \\
128,45 \\
334,25\end{array}$ & $\begin{array}{l}85,37 \\
179,17\end{array}$ & $\begin{array}{l}257,92 \\
\mathbf{8 7 , 6 6}\end{array}$ & 215,60 & 644,53 \\
\hline II & & $\begin{array}{l}0 \\
44,31 \\
28,78\end{array}$ & $\begin{array}{l}84,53 \\
94,68\end{array}$ & $\begin{array}{l}185,77 \\
107,36\end{array}$ & 72,38 & 117,00 \\
\hline III & & & $\begin{array}{l}51,68 \\
24,20\end{array}$ & $\begin{array}{l}208,95 \\
76,43\end{array}$ & 78,91 & 243,16 \\
\hline IV & & & & $\begin{array}{l}71,59 \\
0\end{array}$ & 74,96 & 330,74 \\
\hline V & & & & & 0 & 301,60 \\
\hline VI & & & & & & 0 \\
\hline
\end{tabular}

a Valores em negrito referem-se ao estádio vegetativo.

b Valores em itálico referem-se ao estádio reprodutivo.

${ }^{\circ}$ Valores em negrito italizado referem-se ao estádio produtivo.

Em relação aos grupos formados (Tabela 2) nos dois estádios analisados, apenas os acessos L 2 ('Long Green'), L 5 ('E - 22'), L 11 ('Annamalai Brinjal'), L 12 ('Indiana') e L 13 (PI 319855), permaneceram no mesmo grupo. O acesso L 4 ('Florida Market'), que, com base nos 
caracteres vegetativos, formou um grupo isolado de todos os demais em relação ao estádio reprodutivo, ocupou o último grupo, porém dividindo-o com o acesso L 15 (Sel ESALQ 2).

Constatou-se que os caracteres NMFI, NMFRI, NMP, CMP e PC (Tabela 4) foram os que menos contribuíram para a divergência genética, com base em dados reprodutivos.

\subsubsection{Estádio produtivo}

A estatística $\Lambda\left(\Lambda=2,52 \times 10^{-4}\right)$ de Wilks, transformada para 0 correspondente valor de $F(90 ; 159,74)=8,004$ aplicada aos caracteres do estádio produtivo, detectou diferenças significativas $(P<0,001)$ entre os vetores de médias dos acessos. Observou-se a formação de seis grupos (Tabela 2), com valores de distância média inter-grupo superiores aos dois estádios anteriores (Tabela 5), demostrando dessa forma maior capacidade deste conjunto de caracteres em discriminar este conjunto de acessos. O par de acessos mais divergente foi $L 4$ ('Florida Market') e $L 12$ ('Indiana'), com $D^{2}=674,98$, e o menos divergente, como no estádio reprodutivo, foi $L 2$ ('Long Green') e L12 ('Indiana') com D² = 1,63 (Tabela 7).

Segundo o critério de Singh (1981), os caracteres que menos contribuíram para a divergência (Tabela 4) foram PMF e PROD. 


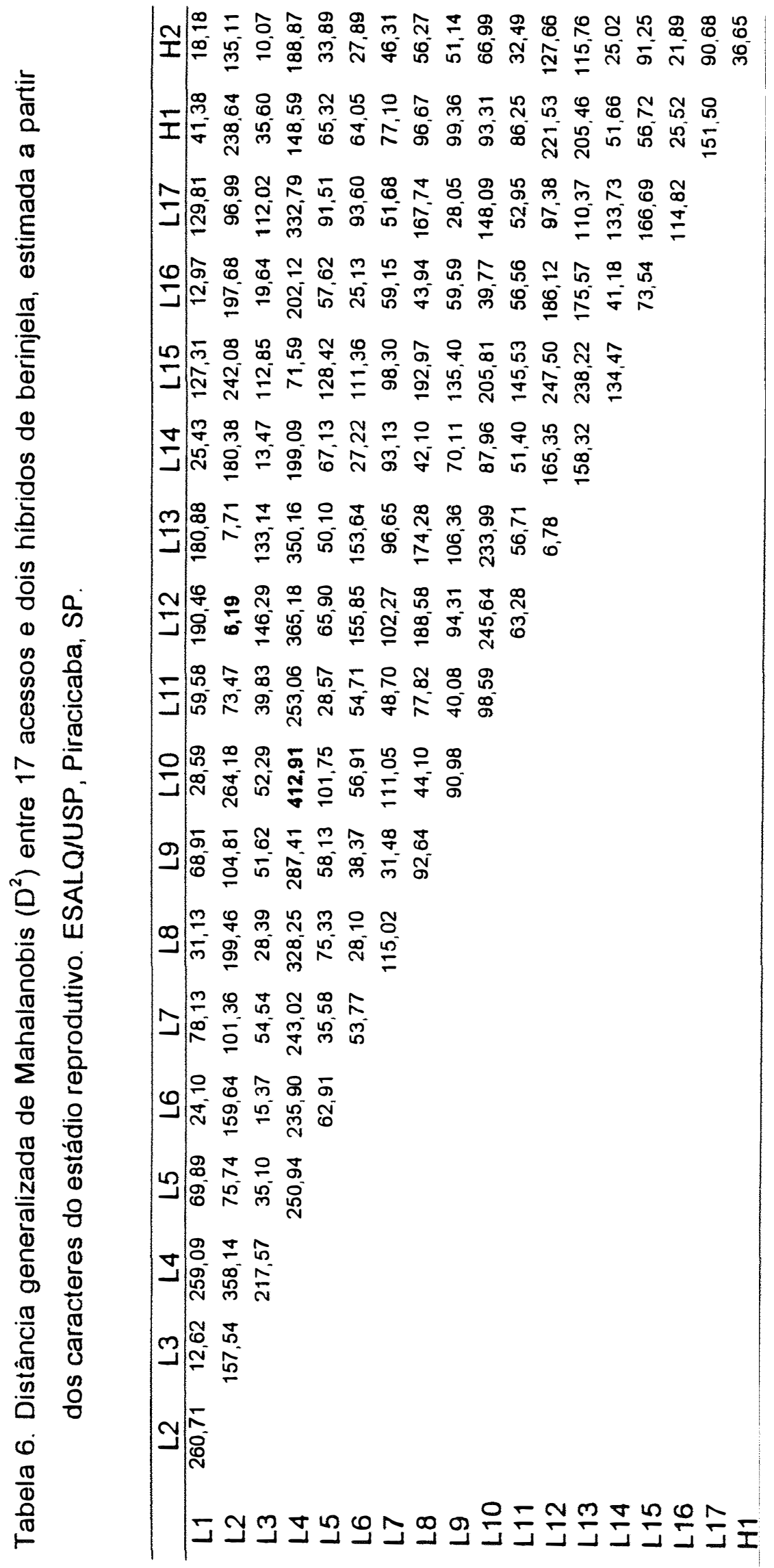




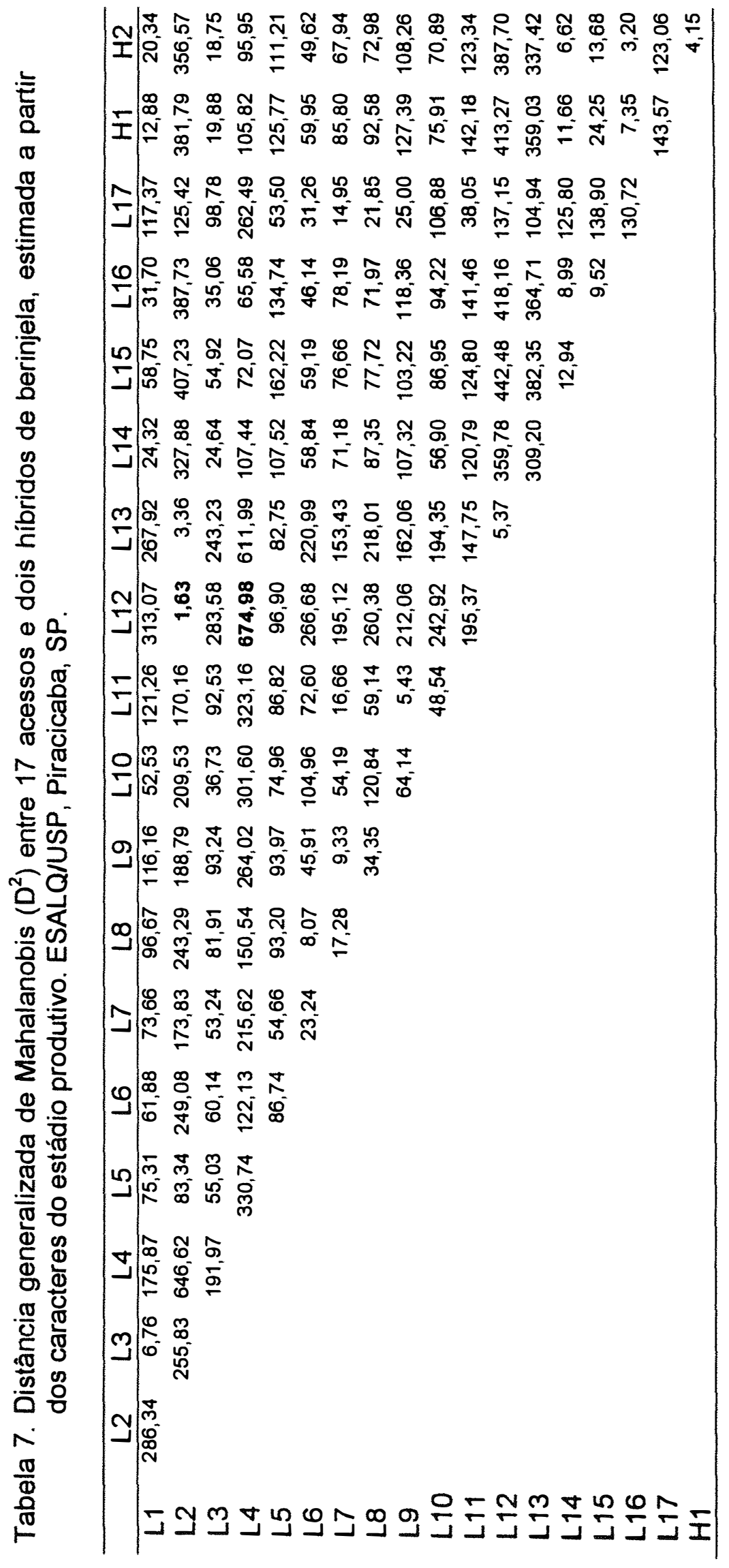




\subsection{Discussão}

Observou-se que os acessos L 2 ('Long Green'), L 12 ('Indiana') e L 13 (PI 319855) mantiveram-se sempre em um mesmo grupo (Tabela 2), independentemente do estádio analisado, evidenciando a proximidade genética existente entre estes acessos.

Em relação aos acessos L1 (PI206472), L3 ('Campineira'), L 6 (PI 169667), L 14 (Sel ESALQ 1) e L 16 ( Sel ESALQ 3), pôde-se observar que (Tabela 2) que estes se mantiveram sempre juntos aos híbridos $\mathrm{H} 1$ ('Nápoli') e H 2 ('Super F100'), nos três estádios analisados. Assim, existe similaridade entre estes acessos e os híbridos, que são cultivados comercialmente no Brasil; desse modo, estes acessos poderiam ser utilizados como genitores em programas de melhoramento visando produção comercial de frutos.

A correlação de Spearman, estimada em relação à distância obtida entre pares de acessos (Tabela 8), nos três estádios analisados, é maior entre estádios contíguos (Veg e Rep $=0,30$; Rep e Prod $=0,73$ ) que entre estádios mais distantes (Veg e Prod $=0,16$ ). A significância desses valores demonstra existir associação entre as divergências estimadas em todos os estádios do desenvolvimento de berinjela.

O coeficiente de coincidência (Tabela 8) estimado para os 20 mais e menos divergentes pares de acessos, em relação aos três estádios de desenvolvimento, seguiu o mesmo padrão demonstrado pela correlação de Spearman, ou seja, maior entre estádios contíguos e menor entre estádios mais distantes. Assim, a utilização dos resultados do estádio reprodutivo como indicativo do estádio produtivo, cuja correlação de Spearman entre estes estádios foi de 0,73 e o coeficiente de coincidência de $50 \%$ para os 20 pares mais divergentes e $15 \%$ para os mais similares, pode ser de interesse prático, pois podem-se obter estes dados em apenas 70 dias pós-transplantio, enquanto para se avaliar convenientemente o estádio produtivo leva-se até 150 
dias pós-transplantio. No entanto, a utilização dos resultados do estádio reprodutivo como indicativo do estádio produtivo pode levar a interpretações errôneas em termos de similaridade e divergência, uma vez que, com os dados do estádio reprodutivo, formaram-se apenas quatro grupos, enquanto que foram formados seis grupos com os dados do estádio produtivo.

Tabela 8. Correlações de Sperman ( $\left.r_{s}\right)$ e coeficiente de coincidência para os 20 pares mais divergentes e mais similares, analisados entre os resultados obtidos com os conjuntos de dados Vegetativos (Veg.), Reprodutivos (Rep.) e Produtivos (Prod.). ESALQ/USP, Piracicaba, SP.

\begin{tabular}{llcc}
\hline Estádios & $r_{S}$ & Divergentes $(\%)$ & Similares (\%) \\
\hline Veg $\times$ Rep & $0,30^{\star \star}$ & 55 & 20 \\
Veg $\times$ Prod & $0,16^{\star}$ & 25 & 15 \\
Rep $\times$ Prod. & $0,73^{\star \star}$ & 50 & 15 \\
\hline
\end{tabular}

${ }^{\star} P<0,05 ;{ }^{* \star P}<0,01$.

Analisando a variação na estrutura e composição dos grupos, observa-se que muitos acessos foram alocados em grupos diferentes em cada estádio analisado. Como exemplo, tem-se o acesso L 10 (PI 166995), o qual, com base nos caracteres do estádio vegetativo, divergiu apenas do acesso $L 4$ ('Florida Market'). Em relação aos caracteres do estádio reprodutivo, o acesso L 10 se mostrou similar aos hibridos H 1 ('Nápoli') e H 2 ('Super F100'); porém, com relação aos caracteres do estádio produtivo o acesso $L 10$ foi alocado em grupo diferente do destes híbridos. Da mesma forma, os acessos L 4 ('Florida Market'), L 5 ('E-22'), L 7 (PI 210026), L 8 (PI 224690), L 9 (PI 269953), L 11 
('Annamalai Brinjal') e L 15 (Sel ESALQ 2) foram alocados em diferentes grupos, em relação aos diferentes estádios.

O que foi exposto anteriormente caracteriza a inconsistência em número e composição dos grupos formados nos três estádios analisados. Tal fato ocorre pois, cada caráter analisado é codificado por vários genes, que são específicos; assim, quando se analisa a divergência genética em relação a um determinado grupo de caracteres, está se avaliando a divergência em relação a um conjunto de genes específicos, os quais podem ou não estar ligados a outros conjuntos de genes de outros caracteres.

Dessa forma, fica claro que a divergência genética estimada entre pares de acessos relaciona-se a um determinado estádio, ou melhor, ao conjunto de caracteres utilizados para estimá-la. Se o interesse do melhorista é selecionar acessos para um programa de melhoramento visando obtenção de híbridos ou segregantes transgressivos, em geraçōes posteriores, este deve trabalhar com caracteres relacionados aos objetivos almejados. Por outro lado, se o objetivo for avaliar um conjunto de acessos, com vistas à determinação de uma coleção nuclear (Holbrook et al., 1993) de um banco de germoplasma, deve-se trabalhar com o conjunto de caracteres do estádio produtivo, por ser 0 estádio com maior potencial para discriminar estes acessos.

Segundo Cruz et al. (1994c), os caracteres do estádio produtivo são resultantes da ação conjunta dos vários estádios anteriores; desse modo, pequenas diferenças no estádio vegetativo são somadas às do estádio reprodutivo e às diferenças do estádio produtivo, fazendo com a divergência detectada neste último estádio seja a somatória das divergências anteriores. 


\section{Cap. II: ANÁLISE DA CAPACIDADE COMBINATÓRIA EM BERINJELA}

\subsection{Introdução}

Os programas de melhoramento de berinjela (Solanum melongena L.) existentes buscam linhagens, por meio de autofecundações sucessivas, que possibilitem a obtenção de híbridos produtivos e com frutos uniformes. Nesse contexto, os cruzamentos dialélicos mostram-se bastante eficientes, por avaliarem as populações "per se" e as respectivas combinações híbridas (Ramalho et al., 1993).

De acordo com Cruz \& Regazzi (1994), os métodos de análise dialélica têm por finalidade analisar o delineamento genético, provendo estimativas de parâmetros que são utilizados na seleção de genitores para a hibridação e no entendimento dos efeitos gênicos envolvidos na determinação dos caracteres que compõem os objetivos do programa de melhoramento.

Quando se trabalha com amostras que representam populações, podem-se estimar os componentes da variação dos efeitos gênicos (Griffing, 1956), o que contribui para a tomada de decisões concernentes ao futuro do programa de melhoramento (Hallauer \& Miranda Filho, 1988).

Segundo Kempthorne (1956), do ponto de vista aplicado, os cruzamentos dialélicos fornecem estimativas da capacidade geral de combinação (CGC) e da capacidade específica de combinação (CEC). A CGC caracteriza o comportamento médio de um genitor em uma série de 
combinações híbridas e é associada predominantemente à ação aditiva dos genes. A CEC, por sua vez, caracteriza o comportamento de combinações híbridas especificas em relação à média dos genitores e é associada predominantemente à ação dominante dos genes (Sprague \& Tatum, 1942). Além desses parâmetros é possivel estimar a heterose existente entre hibridos e genitores, a qual está associada à diferença de freqüência gênica entre os genitores e ao efeito de dominância do caráter (Hallauer \& Miranda Filho, 1988).

Em razão da importância dessas estimativas, há diversos trabalhos com hortaliças que utilizam a metodologia mencionada, podendo-se citar Melo (1987), que, trabalhando com caracteres relacionados aos componentes primários e secundários da produção de frutos em tomateiro, concluiu que existem caracteres cuja herança tem predominância de efeitos gênicos aditivos, enquanto para outros caracteres os efeitos não-aditivos foram predominantes. Oliveira (1997), selecionando genitores de pimentão para adaptação a ambientes com baixo teor de fósforo $(P)$, concluiu que existem linhagens que apresentaram estimativas significativamente altas para CGC dos caracteres envolvidos na adaptação a esses ambientes e que, portanto, podem-se desenvolver programas de melhoramento intra-populacionais a partir da hibridação destas, visando a obtenção de variedades com potencial produtivo para estes ambientes. Resposta similar foi obtida por Amaral Júnior et al. (1996), trabalhando com tomateiro, visando seleção de genitores para caracteres relacionados à qualidade nutricional.

De acordo com Russel \& Eberhart (1975), o estudo da capacidade combinatória de grande número de genitores, por meio de cruzamentos dialélicos, torna-se impraticável em função do número de polinizações necessárias e das dificuldades das operações de campo. Por exemplo, Pacheco (1997) avaliou um cruzamento dialélico com 27 genitores de milho e analisou 378 tratamentos.

Por outro lado, ao se avaliar pequeno número de genitores e combinações híbridas, os estimadores da CGC ficam sujeitos a grande variação 
residual, e o reduzido número de graus de liberdade, associado aos efeitos da CEC, pode dificultar os testes estatísticos (Cruz \& Regazzi, 1994). A análise de pequeno número de genitores reduz a probabilidade de serem encontradas as melhores combinações híbridas.

Para contornar tais problemas, Kempthorne \& Curnow (1961) apresentaram o esquema de dialelo circulante, em que são avaliados $\mathbf{p}$ genitores, representados em s combinações hibridas/genitor, sendo s menor que o número de combinações híbridas exigidas nos dialelos (Cruz \& Regazzi, 1994).

Os dialelos circulantes possibilitam, assim, analisar maior número de genitores com menor número de polinizações e menor dispêndio de recursos. Gonçalves (1987) e Dantas (1988) enfatizaram a eficiência desta metodologia do ponto de vista prático para se estimar a capacidade geral de combinação dos genitores a partir de número reduzido de combinações híbridas.

Os objetivos deste trabalho foram: avaliar a capacidade geral de combinação de cinco genitores de berinjela, utilizando-se o esquema de análise dialélica circulante; e indicar possiveis combinações híbridas superiores.

\subsection{Material e métodos}

Cinco acessos de berinjela pertencentes ao banco de germoplasma de hortaliças do Departamento de Genética da ESALQ/USP (Tabela 1, capítulo I) foram analisados como genitores: 1 - PI 206472; 2 - 'Long Green'; 3 'Campineira'; 4 - 'Florida Market' e 5 - 'E-22'. Estes genitores foram escolhidos por pertencerem a diferentes grupos, em relação aos caracteres do estádio produtivo (Tabela 2, capítulo I), o que denota divergência genética entre eles. As únicas exceções são com relação aos genitores 1 e 3, que, apesar de pertencerem a um mesmo grupo, foram escolhidos por apresentarem características de fruto dentro dos padrões exigidos pelo consumidor brasileiro. 
Para estabelecer os cruzamentos a serem analisados, utilizou-se algoritmo desenvolvido por Kempthorne \& Curnow (1961), com base nos seguintes fatores:

p: número de genitores a serem estudados;

s: número de combinações hibridas de cada genitor;

$2<s<p-1$ : para dialelos com apenas os $F_{1}$ 's;

$2 \leq \mathbf{s}<\mathbf{p}-1$ : para dialelos com $F_{1}$ 's e genitores;

$\frac{\text { ps }}{2}$ número total de cruzamentos;

$\frac{\mathrm{p}+\mathrm{ps}}{2}$ : número total de tratamentos;

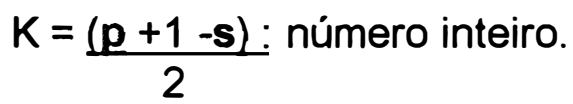

Por este algoritmo, constata-se que $\mathbf{p}$ e s não podem ser par ou impar simultaneamente. Para estabelecer os cruzamentos ij a serem feitos, utilizam-se as seguintes expressões:

$$
\begin{aligned}
& i=1,2, \ldots, p \\
& j=k+i, K+i+1, \ldots \ldots, K+i-1+s .
\end{aligned}
$$

Valores de j acima de $p$ devem ser reduzidos por múltiplos de $\mathbf{p}$, de forma que:

$$
\mathrm{i} \leq \mathrm{j} \leq \mathrm{p} \text {. }
$$

Dessa forma, os cruzamentos analisados foram: $1 \times 3 ; 1 \times 4 ; 2 \times 4$; $2 \times 5$ e $3 \times 5$. Os demais cruzamentos $(1 \times 2,1 \times 5,2 \times 3,3 \times 4$ e $4 \times 5)$ tiveram suas médias preditas de acordo com esta metodologia, com número de combinações híbridas por genitor (s) igual a 2 .

O experimento foi conduzido na área experimental do Departamento de Genética da ESALQ/USP, em Piracicaba - SP, no periodo de agosto de 1996 a janeiro de 1997, em delineamento em blocos ao acaso, com três repetições e parcelas de oito plantas. As quatro plantas centrais 
constituiram a parcela útil. Os tratos culturais foram executados conforme Filgueira (1982).

Foram feitas seis colheitas, tendo sido avaliados os seguintes caracteres (quando os frutos estavam no ponto de colheita comercial):

- Comprimento médio de fruto (CMF), expresso em $\mathrm{cm}$ : foi obtido medindo-se o comprimento médio de dez frutos, no sentido longitudinal, por parcela, em cada colheita. Posteriormente, calculou-se a média do comprimento de fruto a partir das estimativas dos comprimentos médios dos frutos obtidos em cada colheita. Este método foi utilizado para os caracteres DMF e PMF.

- Diâmetro médio de fruto (DMF), expresso em cm: foi obtido medindo-se dez frutos transversalmente, na parte de maior diâmetro dos frutos, por colheita.

- Peso médio de fruto (PMF), expresso em gramas por fruto (g/fruto): foi obtido pela pesagem de dez frutos, por colheita, em balança com precisão de um grama, com posterior cálculo da média aritmética.

- Número médio de frutos por planta (NMFP): somaram-se todos os frutos com padrão comercial colhidos em cada parcela e, posteriormente, dividiu-se por quatro (número de plantas da área útil da parcela).

- Produção total de frutos por planta (PROD), expresso em gramas por planta (g/planta): foi obtida pela soma das pesagens de todos os frutos, com padrão comercial colhidos em cada parcela; posteriormente, dividiu-se por quatro (número de plantas da área útil da parcela).

Foram feitas análises de variâncias univariadas, adotando-se o seguinte modelo estatístico:

$$
\mathrm{Y}_{(\mathrm{j}) \mathrm{k}}=\mu+\mathrm{G}_{\mathrm{ij}}+\mathrm{B}_{\mathrm{k}}+\varepsilon_{(\mathrm{j}) \mathrm{k}}
$$

em que

$Y_{(i j) k:}$ valor observado, relativo ao ij-ésimo genótipo na k-ésima repetição;

$\mu$ : média geral; 


$$
\begin{aligned}
& \mathrm{G}_{\mathrm{ij}} \text { : efeito fixo do ij-ésimo genótipo }(\mathrm{ij}=1,2,3,4,5,{ }) \\
& \mathrm{B}_{\mathrm{k}} \text { : efeito do k-ésimo bloco; } \\
& \mathcal{E}_{(\mathrm{ijk})} \text { : erro experimental associado à observação } Y_{\mathrm{ijk}} .
\end{aligned}
$$

$\mathrm{Na}$ Tabela 1, apresenta-se o esquema da análise de variância e as esperanças dos quadrados médios.

Tabela 1. Esquema da análise de variância dos caracteres relativos à produção de frutos em berinjela.

\begin{tabular}{lllll}
\hline FV & GL & QM & $E(Q M)$ & $F$ \\
\hline Blocos & $b-1$ & QMB & $\sigma^{2}+{ }_{g} \sigma^{2}{ }_{b}$ & \\
Genótipos & $g-1$ & QMG & $\sigma^{2}+r \Phi_{g}$ & QMG/QMR \\
Resíduo & $(b-1)(g-1)$ & QMR & $\sigma^{2}$ & \\
\hline
\end{tabular}

Adicionalmente à análise de variância, estimaram-se as seguintes estatisticas:

a) Componente de variação fenotípica entre médias $\left(\hat{\sigma}_{p}^{2}\right)$, dado pela razão QMG/r.

b) Componente quadrático, que expressa a variabilidade genotípica entre as médias dos genótipos $\left(\hat{\Phi}_{g}\right)$, para modelos fixos, dado pela expressão: QMG-QMR/r.

c) Coeficiente de determinação genotípica $\left(\hat{H}^{2}\right)$, que expressa a confiabilidade do valor fenotípico em predizer o valor genotípico, cuja expressão é:

$$
\hat{H}^{2}=\left[\hat{\Phi}_{g} / \hat{\sigma}_{P}^{2}\right] \times 100
$$


d) Coeficiente de variação experimental $\left(C_{\mathrm{e}}\right)$, dado pela expressão

$$
100 \sqrt{\frac{Q M R}{\hat{m}}} .
$$

A análise dialélica foi realizada conforme Kempthorne \& Curnow (1961), para genitores e híbridos. Cujo modelo estatístico foi:

$$
Y_{\mathrm{ij}}=\mu+g_{\mathrm{i}}+g_{\mathrm{j}}+s_{\mathrm{ij}}+\bar{\varepsilon}_{(\mathrm{j}) .} .
$$

em que

$Y_{\mathrm{ij}}$ : valor médio da combinação híbrida $(\mathrm{i} \neq \mathrm{j})$ ou do genitor $(\mathrm{i}=\mathrm{j})$;

$\mu$ : efeito da média geral;

$g_{1}, g_{\mathrm{J}}$ : efeitos da capacidade geral de combinação do i-ésimo e do j-ésimo genitor;

$s_{\text {I }}$ : efeito da capacidade específica de combinação dos genitores i ej; e

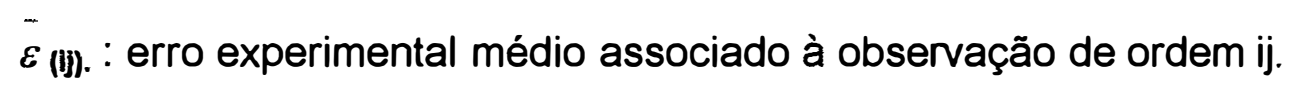

Foram incorporadas restrições nos parâmetros e nas soluções, para que fossem obtidas soluções únicas. Em razão destas restrições, os estimadores dos efeitos para o caso em que são analisados genitores e híbridos $F_{1}$ 's, são:

$$
\hat{\mu}=\frac{2 \mathrm{Y} .}{\mathrm{p}(\mathrm{s}+2)}
$$

em que

$$
Y_{. .}=\sum_{i}^{p} \sum_{j}^{p} Y_{i j}
$$

Os estimadores de $\hat{g}_{\mathbf{l}}$ e $\hat{g}_{\mathbf{j}}$ foram obtidos a partir da solução do sistema:

$$
\mathrm{A}_{\sim}^{\hat{G}}=\underset{\sim}{Q}
$$


em que

$\hat{G}$ : vetor $\mathrm{p} \times 1$ dos estimadores dos efeitos da capacidade geral de combinação;

$\underset{\sim}{Q}:$ vetor $\mathrm{p} \times 1$, cujo i-ésimo elemento é $2 \mathrm{Y}_{(\mathrm{ij})}+\sum_{\mathrm{j}(\mathrm{i}) \neq \mathrm{i}}^{\mathrm{p}} \mathrm{Y}_{\mathrm{ij}}-(\mathrm{s}+2) \hat{\mu}$;

A : matriz $p \times p$, cujos elementos são:

$a_{\|}=s+4$

$a_{\text {jj }}=1(u m)$, para $j=k+i, K+i+1, \ldots ., k+i-1+s ; e$

$a_{\text {j] }}=0$ (zero), para os demais casos.

Os estimadores dos efeitos das capacidades específicas de combinação são dados por:

$$
\hat{s}_{\mathbf{j}}=Y_{\mathbf{i j}}-\hat{\mu}-\hat{g}_{\mathbf{i}}-\hat{g}_{\mathbf{j}} \text {. }
$$

As somas de quadrados dos efeitos da CGC, $S Q(C G C)$, e dos efeitos da CEC, SQ(CEC), são dadas por:

$$
\begin{gathered}
\mathrm{SQ}(\mathrm{CGC})=\sum_{i}^{p} \hat{g}_{i} \mathrm{Y}_{\mathrm{i} . ;} \\
\mathrm{SQ}(\mathrm{CEC})=\sum_{i}^{p} \sum_{j(i)}^{p} \hat{s_{i j}} \mathrm{Y}_{\mathrm{ij}} .
\end{gathered}
$$

A predição do potencial das combinações híbridas, que não foram avaliadas, foi feita por meio do estimador:

$$
Z_{\mathrm{ij}}=\hat{\mu}+\hat{g_{i}}+\hat{g_{j}}
$$

em que

Zij : média predita associada à combinação híbrida ij ( $i \neq j)$;

$\hat{\mu}$ : estimativa da média geral;

$\hat{g}_{i}$ e $\hat{g}_{j}$ : estimativas dos efeitos da capacidade geral de combinação, relativas aos genitores i e j (Cruz \& Regazzi, 1994). 
A heterose percentual foi calculada em relação à média dos genitores.

Os híbridos 'Nápoli' e 'Super F100' foram incluídos para comparação com os híbridos analisados e preditos neste estudo, por serem atualmente cultivados comercialmente no Brasil.

Em todas as análises foi utilizado o programa Genes (Cruz, 1997).

\subsection{Resultados e discussão}

Analisando a Tabela 2, observa-se que os valores dos quadrados médios dos caracteres analisados referentes à capacidade geral de combinação (CGC) e capacidade específica de combinação (CEC) foram significativos $(P<0,01)$, com exceção apenas para CEC relativa ao caráter PROD, cuja significância foi de $5 \%$ pelo teste $\mathrm{F}$. Pela análise dos resultados, pode-se observar que tanto os efeitos gênicos aditivos quanto os não-aditivos estão envolvidos no controle desses caracteres.

Em todos os caracteres analisados, o quadrado médio de CGC foi maior que o CEC (Tabela 2), indicando dessa forma, que os efeitos gênicos aditivos são mais importantes que os não-aditivos. Estes resultados concordam com os obtidos por Lal \& Pathak (1974), também para berinjela. Este fato indica a possibilidade de obtenção de novos cultivares a partir da seleção intrapopulacional na população resultante de combinação dos genitores superiores.

A constatação da maior importância da CGC para os caracteres primários da produção de frutos por planta, em berinjela, indica boa precisão nas estimativas dos híbridos preditos, uma vez que esta é feita somando-se a estimativa da média geral às estimativas das CGCs dos genitores envolvidos.

Em todos os caracteres analisados (Tabela 2) obteve-se boa precisão experimental (C. $V_{\mathrm{e}}$. inferior a $16 \%$ ) e coeficiente de determinação 
genotípica $\left(\hat{H}^{2}\right)$ acima de $80 \%$, significando alta confiabilidade dos valores fenotípicos em representar os valores genotípicos.

Tabela 2. Resumo das análises de variâncias, estimativas dos quadrados médios da capacidade geral de combinação (CGC), da capacidade específica de combinação (CEC), média, coeficiente de variação (C. $V_{\mathrm{e}}$ ) e coeficiente de determinação genotípica $\left(\hat{H}^{2}\right)$ para cinco caracteres de produção de frutos em berinjela. ESALQ/USP, Piracicaba, SP.

\begin{tabular}{lcrrrrr}
\hline & & \multicolumn{5}{c}{ Quadrados Médios (1) } \\
\cline { 3 - 7 } FV & GL & CMF & DMF & PMF & NMFP & PROD \\
\hline Blocos & 2 & 1,28 & 0,03 & 269,16 & 9,68 & 177565,82 \\
Tratamentos & 9 & $9,71^{\star \star}$ & $7,49^{\star \star}$ & $22734,01^{\star \star}$ & $168,80^{\star \star}$ & $883341,42^{\star \star}$ \\
CGC & 4 & $15,74^{\star \star}$ & $13,16^{\star \star}$ & $39878,87^{\star \star}$ & $345,71^{\star \star}$ & $1539613,00^{\star \star}$ \\
CEC & 5 & $4,89^{\star \star}$ & $2,86^{\star \star}$ & $9018,13^{\star \star}$ & $27,27^{\star \star}$ & $358322,31^{\star}$ \\
CGC/CEC & & 3,21 & 4,60 & 4,42 & 12,67 & 4,29 \\
Resíduo & 18 & 0,54 & 0,09 & 300,99 & 3,17 & 163326,01 \\
\hline Média & & 13,91 & 6,25 & 190,95 & 15,85 & 2529,06 \\
C.V.(\%) & & 5,32 & 4,88 & 9,09 & 8,59 & 15,98 \\
$\hat{H}^{2}(\%)$ & & 94,35 & 98,75 & 98,67 & 96,41 & 81,51 \\
\hline
\end{tabular}

**; *: $P<0,01$ e $P<0,05$, respectivamente.

(1) CMF: comprimento médio de frutos; DMF: diâmetro médio de frutos; PMF: peso médio de frutos; NMFP: número médio de frutos por planta; PROD: produção total de frutos por planta.

Na Tabela 3 observam-se as estimativas dos efeitos da CGC $\left(\hat{g_{i}}\right)$ dos genitores para os cinco caracteres. Sabe-se que altas estimativas de $\hat{g}_{i}$, em valores absolutos, ocorrem para genótipos cujas freqüências de alelos favoráveis são maiores ou menores do que a freqüência média dos alelos em todos os genótipos analisados (Vencovsky, 1970) e que estas estimativas são indicativas da importância dos efeitos aditivos dos genes (Sprague \& Tatum, 
1942). Neste sentido, os genitores PI 206472 e 'Campineira' (Tabela 3) apresentaram valores positivos de $\hat{g}_{i}$ para os caracteres CMF, DMF, PMF e PROD, indicando boa concentração de alelos favoráveis para estes caracteres. Observa-se o mesmo comportamento para o genitor 'Florida Market' (Tabela 3) relacionado aos caracteres DMF e PMF, enquanto 'Long Green' pode contribuir positivamente para o caráter NMFP.

Tabela 3. Estimativas dos efeitos da capacidade geral de combinação $\left(\hat{g_{i}}\right)$ para cinco caracteres de cinco genitores de berinjela. ESALQ/USP, Piracicaba, SP.

\begin{tabular}{lcrrrr}
\hline & \multicolumn{5}{c}{ Caracteres } \\
\cline { 2 - 6 } Genitores & CMF & DMF & PMF & NMFP & PROD \\
\hline PI 206472 & 0,88 & 0,18 & 17,23 & $-0,80$ & 375,65 \\
'Long Green' & $-1,33$ & $-1,46$ & $-77,36$ & 7,94 & $-323,65$ \\
'Campineira' & 0,76 & 0,42 & 25,11 & $-1,97$ & 116,79 \\
'Florida Market' & $-0,22$ & 0,93 & 48,56 & $-4,47$ & $-264,60$ \\
'E-22' & $-0,09$ & $-0,07$ & $-13,54$ & $-0,70$ & 95,81 \\
\hline
\end{tabular}

(') CMF: comprimento médio de frutos; DMF: diâmetro médio de frutos; PMF: peso médio de frutos; NMFP: número médio de frutos por planta; PROD: produção total de frutos por planta.

Os genitores PI 206472, 'Florida Market', 'Long Green' e 'Campineira' podem ser utilizados em diferentes programas de melhoramento, de acordo com objetivos previamente definidos, visando a seleção de novos cultivares ou formação de híbridos. Em termos gerais, os genitores PI 206472 e 'Campineira' foram considerados os mais promissores, por apresentarem valores positivos de $\hat{g}_{i}$ para quatro, dentre os cinco componentes primários da produção de frutos em berinjela analisados neste estudo. Estes genitores apresentaram $\hat{g}_{i}$ negativo apenas para NMFP. 
$\mathrm{Na}$ tabela 4, encontram-se as estimativas dos efeitos de CEC $\left(\mathrm{s}_{\mathrm{ii}} \mathrm{e}\right.$ $s_{i j}$ ) segundo Cruz \& Vencovsky (1989) $s_{i i}$ é uma medida da divergência genética do genitor $i$, em relação aos demais genitores analisados no dialelo. Assim quanto maior o valor absoluto de um genitor, maior sua contribuição para a heterose de seus híbridos, do seguinte modo: se $s_{i i}$ for negativo, o genitor $i$ contribuirá positivamente para a heterose, se positivo contribuirá negativamente. Analisando os $s_{i i}$ (Tabela 4) observou-se, com relação ao genitor 5 ('E-22'), valores negativos para os caracteres CMF, DMF, PMF e $P R O D$, podendo-se inferir que este genitor expressará valores positivos de heterose para esses caracteres, quando em combinação híbrida com outros genitores analisados neste estudo, tal fato pôde ser observado na Tabela 5. O genitor 'Florida Market', pode ser utilizado em programas de melhoramento que visem o aumento de número de frutos por planta (NMFP), pois este genitor apresentou valor negativo de $\mathrm{s}_{\mathrm{ii}}$ e os híbridos com maiores valores de heterose (Tabela 5) para este caráter. Para os caracteres CMF, DMF, PMF, e NMFP existem genitores com valores de $s_{i i}$ positivos e negativos, ilustrando a hipótese de dominância bidirecional, segundo a qual, existem genes dominantes que aumentam a expressão do caráter e outros igualmente dominante que a reduzem (Cruz \& Vencovsky, 1989).

Valores de $s_{i j}$ (Tabela 4), são diretamente proporcionais à heterose, uma vez que a média dos híbridos analisados é obtida somando-se à estimativa da média geral as CGCs dos genitores e a CEC. Em relação a esse aspecto, dentre os hibridos analisados, pode-se observar que o híbrido $2 \times 4$ ('Long Green' x 'Florida Market'), cujo $s_{i j}$ é o maior para o caráter PROD (Tabela 4), apresenta o maior valor de heterose para este caráter (Tabela 5). Comportamento similar pode ser observado para o hibrido $3 \times 5$ ('Campineira' $x$ 'E-22'), com valores positivos de $s_{i j}$ para os caracteres CMF, DMF, PMF e PROD (Tabela 4), indicando, assim, valores positivos de heterose (Tabela 5) deste híbrido para estes caracteres. 
Em programas de melhoramento, interessa incluir genitores de alto potencial genético aditivo e que apresentem complementação gênica, de forma que a população filial, derivada das hibridações entre os genitores, apresente alta variabilidade genotípica. Esta complementação gênica pode ser avaliada pela capacidade específica de combinação $\left(s_{i j}\right)$, que expressa a diversidade existente entre os genitores. Neste sentido, os genitores PI 206472 e 'Campineira' apresentaram valores positivos de $s_{i j}$ (Tabela 4) para os caracteres DMF, PMF e PROD, demonstrando que estes genitores, apontados como os de maior valor genético aditivo, apresentam complementação gênica para estes caracteres. Assim, populações derivadas deste cruzamento serão de grande interesse para os propósitos do melhoramento, em função da possibilidade de selecionar genótipos cujas médias destes caracteres sejam superiores aos genitores.

Tabela 4. Estimativas dos efeitos da capacidade específica de combinação ( $s_{\| i} e$ $\left.s_{i j}\right)$ para cinco caracteres de berinjela. ESALQ/USP, Piracicaba, SP.

\begin{tabular}{crrrrr}
\hline & \multicolumn{5}{c}{ Caracteres (1) } \\
\cline { 2 - 6 } Efeitos (sii e siij) & CMF & DMF & \multicolumn{1}{c}{ PMF } & NMFP & \multicolumn{1}{c}{ PROD } \\
\hline $1 \times 1\left(^{2}\right.$ ) & $-0,04$ & 0,11 & 1,99 & $-0,58$ & $-177,04$ \\
$1 \times 3$ & $-1,40$ & 0,54 & 32,47 & $-0,83$ & 231,83 \\
$1 \times 4$ & 1,48 & $-0,76$ & $-36,45$ & 2,00 & 122,25 \\
$2 \times 2$ & $-0,69$ & 0,34 & 13,55 & 1,05 & $-243,45$ \\
$2 \times 4$ & 0,91 & $-1,05$ & $-44,15$ & 1,65 & 531,62 \\
$2 \times 5$ & 0,48 & 0,36 & 17,04 & $-3,77$ & $-44,72$ \\
$3 \times 3$ & 0,34 & $-0,71$ & $-49,43$ & 1,67 & $-175,50$ \\
$3 \times 5$ & 0,71 & 0,88 & 66,40 & $-2,51$ & 119,17 \\
$4 \times 4$ & $-1,19$ & 0,91 & 40,30 & $-1,82$ & $-326,93$ \\
$5 \times 5$ & $-0,60$ & $-0,62$ & $-41,72$ & 3,14 & $-37,23$ \\
\hline
\end{tabular}

(') CMF: comprimento médio de frutos; DMF: diâmetro médio de frutos; PMF: peso médio de frutos; NMFP: número médio de frutos por planta; PROD: produção total de frutos por planta.

$\left(^{2}\right)$ 1: PI 206472; 2: 'Long Green'; 3: 'Campineira'; 4: 'Florida Market'; 5: 'E-22'. 
Comparando as médias dos híbridos 'Nápoli' e 'Super F100' com as médias dos híbridos analisados e dos preditos (Tabela 6), verificou-se que os híbridos $1 \times 3,1 \times 4,1 \times 5$ e $3 \times 5$ apresentaram estimativas de médias dos diversos caracteres iguais ou superiores a híbridos cultivados comercialmente no Brasil, demonstrando assim forte potencial comercial.

Tabela 5. Estimativas das médias de cinco genitores de berinjela e de seus respectivos híbridos e heterose percentual, referente a cinco componentes da produção de frutos em berinjela. ESALQ/USP, Piracicaba, SP.

\begin{tabular}{|c|c|c|c|c|c|c|c|c|c|c|}
\hline \multirow{3}{*}{ Genótipos } & \multicolumn{10}{|c|}{ Caracteres (') } \\
\hline & \multicolumn{2}{|c|}{ CMF } & \multicolumn{2}{|c|}{$\mathrm{DMF}$} & \multicolumn{2}{|c|}{ PMF } & \multicolumn{2}{|c|}{ NMFP } & \multicolumn{2}{|c|}{ PROD } \\
\hline & $\begin{array}{c}\text { média } \\
\mathrm{cm}\end{array}$ & $\begin{array}{c}\text { heterose } \\
(\%)\end{array}$ & $\begin{array}{c}\text { Média } \\
\mathrm{cm}\end{array}$ & $\begin{array}{c}\text { heterose } \\
(\%)\end{array}$ & $\begin{array}{c}\text { média } \\
\mathrm{g}\end{array}$ & $\begin{array}{c}\text { heterose } \\
(\%)\end{array}$ & média & $\begin{array}{c}\text { heterose } \\
(\%)\end{array}$ & $\begin{array}{c}\text { média } \\
\mathrm{g} / \mathrm{pl}\end{array}$ & $\begin{array}{c}\text { heterose } \\
(\%)\end{array}$ \\
\hline $1\left(^{2}\right)$ & 15,63 & -1 & 6.73 & -2 & 22742 & -1 & 13,66 & -10 & 3103,33 & -1 \\
\hline 2 & 10,54 & - & 3,65 & - & 49,77 & - & 32,83 & - & 1638,28 & - \\
\hline 3 & 15,80 & - & 6,38 & - & 191,75 & - & 13,58 & - & 2587,14 & - \\
\hline 4 & 12,26 & - & 9,04 & - & 328,38 & - & 5,08 & - & 1672,91 & - \\
\hline 5 & 13,11 & - & 5,47 & - & 122,13 & - & 21,75 & - & 2683,45 & - \\
\hline$\cdot 1 \times 2\left(^{3}\right)$ & 13,45 & 2,79 & 4,96 & $-4,43$ & 130,82 & $-5,60$ & 22,79 & $-1,93$ & 2581,04 & 8,86 \\
\hline$+1 \times 3\left(^{4}\right)$ & 14,16 & $\begin{array}{l}-9,89 \\
-9\end{array}$ & 7,41 & 13,12 & 265,77 & 26,81 & 12,25 & $-10,05$ & 3253,33 & 14,34 \\
\hline$+1 \times 4$ & 16,05 & 15,09 & 6,61 & $-16,16$ & 220,29 & $-20,73$ & 12,58 & 34,25 & 2762,36 & 15,67 \\
\hline$\cdot 1 \times 5$ & 14,69 & 2,22 & 6,36 & 4,26 & 194,64 & 11,36 & 15,85 & $-10,47$ & 3000,52 & 3,70 \\
\hline$\cdot 2 \times 3$ & 13,34 & 1,29 & 5,20 & 3,68 & 138,70 & 14,85 & 21,34 & $-8,03$ & 2322,19 & 9,91 \\
\hline$+2 \times 4$ & 13,26 & 16,31 & 4,66 & $-26,55$ & 117,99 & $-37,59$ & 21,00 & 10,78 & 2472,42 & 49,33 \\
\hline$+2 \times 5$ & 12,96 & 9,59 & 5,06 & 10,96 & 117,08 & 36,22 & 19,33 & $-29,16$ & 2256,48 & 4,42 \\
\hline$\cdot 3 \times 4$ & 14,45 & 2,99 & 7,61 & $-1,29$ & 264,63 & 1,75 & 9,19 & $-1,50$ & 2381,25 & 11,79 \\
\hline$+3 \times 5$ & 15,30 & 5,84 & 7,48 & 26,24 & 268,92 & 71,35 & 10,66 & $-39,65$ & 2860,83 & 8,55 \\
\hline $.4 \times 5$ & 13,58 & 7,05 & 7,11 & $-1,99$ & 225,96 & 0,31 & 12,18 & $-9,20$ & 2360,26 & 8,35 \\
\hline
\end{tabular}

( ${ }^{1}$ ) CMF: comprimento médio de frutos; DMF: diâmetro médio de frutos; PMF: peso médio de frutos; NMFP: número médio de frutos por planta; PROD: produção total de frutos por planta.

$\left({ }^{2}\right)$ 1: PI 206472; 2: 'Long Green'; 3: 'Campineira'; 4: 'Florida Market'; 5: 'E-22'.

(3) $:$ : híbrido predito;

$(4)+$ : híbrido e analisado

Merece destaque o híbrido $1 \times 5$ (PI $206472 \times$ ' $E$ - 22'), cujas médias foram preditas (Tabela 6 ), portanto sem 0 efeito de $s_{i j}$, pois, suas 
estimativas de médias são próximas a dos híbridos 'Nápoli' e 'Super F100' , sendo, pois, viável sua inclusão em futuros estudos.

Tabela 6. Estimativas das médias de cinco caracteres, de híbridos preditos, analisados e comerciais de berinjela. ESALQ/USP, Piracicaba, SP.

\begin{tabular}{cccccc}
\hline Hibridos $\left(^{2}\right)$ & CMF & DMF & PMF & NMF & PROD \\
\hline$\cdot 1 \times 2\left(^{3}\right)$ & 13,45 & 4,96 & 130,82 & 22,79 & 2581,04 \\
$+1 \times 3\left(^{4}\right)$ & 14,16 & 7,41 & 265,77 & 12,25 & 3253,33 \\
$+1 \times 4$ & 16,05 & 6,61 & 220,29 & 12,58 & 2762,36 \\
$\cdot 1 \times 5$ & 14,69 & 6,36 & 194,64 & 15,85 & 3000,52 \\
$\bullet 2 \times 3$ & 13,34 & 5,20 & 138,70 & 21,34 & 2322,19 \\
$+2 \times 4$ & 13,26 & 4,66 & 117,99 & 21,00 & 2472,42 \\
$+2 \times 5$ & 12,96 & 5,06 & 117,08 & 19,33 & 2256,48 \\
$\bullet 3 \times 4$ & 14,45 & 7,61 & 264,63 & 9,19 & 2381,25 \\
$+3 \times 5$ & 15,30 & 7,48 & 268,92 & 10,66 & 2860,83 \\
$\cdot 4 \times 5$ & 13,58 & 7,11 & 225,96 & 12,18 & 2360,26 \\
Nápoli( $\left(^{5}\right)$ & 15,81 & 7,24 & 252,35 & 9,83 & 2482,91 \\
Super & & & & & \\
F100(5) & 15,48 & 7,12 & 236,33 & 10,83 & 2549,16 \\
\hline
\end{tabular}

( ${ }^{1}$ ) CMF: comprimento médio de frutos; DMF: diâmetro médio de frutos; PMF: peso médio de frutos; NMFP: número médio de frutos por planta; PROD: produção total de frutos por planta.

$\left(^{2}\right)$ 1: PI 206472; 2: 'Long Green'; 3: 'Campineira'; 4: 'Florida Market'; 5: “E-22'.

(3) $\bullet$ : híbrido predito.

(4) +: híbrido analisado.

$\left({ }^{5}\right)$ : híbrido comercial. 


\section{Cap. III: RELAÇÃO ENTRE DIVERGÊNCIA GENÉTICA DE GENITORES DE BERINJELA E DESEMPENHO DE SEUS HÍBRIDOS}

\subsection{Introdução}

O mercado consumidor brasileiro exige cada vez mais produtos olerícolas com apresentação visual boa e uniforme, além de preço acessivel. No caso da berinjela, tais exigências levam à utilização de híbridos, em razão da uniformidade e da grande produção por planta.

$\mathrm{Na}$ obtenção de híbridos, o parâmetro de maior interesse é o desempenho médio dos híbridos (Cruz et al., 1994a). Os fatores genéticos que determinam este desempenho envolvem desvios de dominância dos caracteres, diferenças de freqüências gênicas entre genitores, efeitos gênicos de natureza aditiva, além dos desvios epistáticos (Falconer \& Mackay, 1996).

Cruz et al. (1994b) concluíram que a hibridação de genitores divergentes possibilita maior efeito heterótico na progênie e maior probabilidade de recuperar genótipos superiores nas gerações segregantes posteriores. Atualmente diversos autores têm demonstrado a associação entre divergência genética entre genitores e desempenho dos seus híbridos respectivos (Amaral Júnior, 1996; Dias \& Kageyama, 1997b; Manjarrez-Sandoval et al., 1997; Saghai Maroof et al. , 1997). Tal associação acontece, pois a divergência genética está relacionada à diferença de freqüência gênica entre genitores $e$, dessa forma, associada ao fenômeno da complementação gênica (Ghaderi et al., 1984), que, por sua vez, está ligada à heterose e à capacidade específica de combinação (Bernardo, 1992). 
Entretanto, Arunachalam \& Bandyopadhyay (1984), estudando associação entre divergência genética, entre genitores, e desempenho dos híbridos, concluíram que esta associação é positiva dentro de limites máximos e mínimos de divergência entre genitores e que, dentro desses limites, o número de híbridos com bom desempenho foi maior que fora destes. Resultado semelhante foi também obtido por Dias \& Kageyama (1997b), ao estudarem a associação da divergência genética entre clones de cacaueiro e o desempenho de seus híbridos.

Trabalhando com predição de desempenho de híbridos a partir da divergência entre genitores, Cruz et al. (1994b) concluíram que os cruzamentos devem ser feitos entre genitores divergentes, mas que apresentem também bom desempenho em relação aos principais caracteres, dentro dos objetivos de um programa de melhoramento. Segundo Lal \& Pathak (1974), trabalhando com berinjela, genitores com bom desempenho apresentam alta capacidade geral de combinação (Griffing, 1956), o que é indicativo de grande concentração de alelos favoráveis (Vencovsky, 1970).

Assim, os objetivos do presente trabalho foram: estimar a correlação existente entre divergência genética entre genitores e desempenho dos híbridos; e avaliar a eficiência do procedimento de Arunachalam \& Bandyopadhyay (1984) e do método da classificação dupla na seleção de genitores. O método da classificação dupla consiste em classificar os genitores em relação aos caracteres avaliados e, posteriormente, selecionar, dentre os melhores, os pares mais divergentes para serem utilizados em cruzamentos.

\subsection{Material e métodos}

Utilizaram-se cinco acessos de berinjela do banco de germoplasma de hortaliças do Departamento de Genética da ESALQ/USP, como genitores (1 - PI 206472, 2 - 'Long Green', 3 - 'Campineira,; 4 - 'Florida Market' e 5 - 'E-22'). As razões para estas escolhas foram apresentadas no capítulo II. 
O experimento foi conduzido na área experimental do Departamento de Genética da ESALQ/USP, no período de agosto de 1996 a janeiro de 1997, em Piracicaba - SP, no delineamento de blocos ao acaso, com três repetições e parcelas de oito plantas. $A$ área útil incluiu as quatro plantas centrais. Os tratos culturais foram executados conforme Filgueira (1982).

De acordo com o método de Kempthorne \& Curnow (1961) para dialelo circulante, incluindo os genitores em duas combinações híbridas por genitor $(s=2)$, foram analisados os genótipos: $1 ; 2 ; 3 ; 4 ; 5 ; 1 \times 3 ; 1 \times 4 ; 2 \times 4$; $2 \times 5$; e $3 \times 5$. As médias dos híbridos $(1 \times 2 ; 1 \times 5 ; 2 \times 3 ; 3 \times 4 ; 4 \times 5)$ foram preditas conforme o método referido anteriormente, somando-se à estimativa da média geral as estimativas dos efeitos de capacidade geral de combinação dos respectivos genitores, cuja expressão é

$$
\mathrm{Z}_{i j}=\hat{\mu}+\hat{g}_{i}+\hat{g}_{j}
$$

em que

$Z_{i j}$ : média predita associada à combinação híbrida ij $(i \neq j)$;

$\hat{\mu}$ : estimativa da média geral;

$\hat{g_{i}}$ e $\hat{g_{j}}$ : estimativas dos efeitos da capacidade geral de combinação. Estes valores foram estimados conforme metodologia de Kempthorne \& Curnow (1961), descrita no capítulo II.

Foram feitas seis colheitas, tendo sido avaliados os seguintes caracteres, no ponto de colheita comercial:

- Comprimento médio de fruto (CMF), expresso em $\mathrm{cm}$ : foi obtido medindo-se o comprimento médio de dez frutos, no sentido longitudinal, por parcela, em cada colheita. Posteriormente, calculou-se a média do comprimento de fruto a partir das estimativas dos comprimentos médios dos frutos obtidos em cada colheita. Este método foi utilizado para os caracteres DMF e PMF.

- Diâmetro médio de fruto (DMF), expresso em cm: foi obtido medindo-se dez frutos transversalmente, na parte de maior diâmetro dos frutos, por colheita. 
- Peso médio de fruto (PMF), expresso em gramas por fruto (g/fruto): foi obtido pela pesagem de dez frutos, por colheita, em balança com precisão de um grama, com posterior cálculo da média aritmética.

- Número médio de frutos por planta (NMFP): somaram-se todos os frutos com padrão comercial colhidos em cada parcela e, posteriormente, dividiu-se por quatro (número de plantas da área útil da parcela).

- Produção total de frutos/planta (PROD), expressa em gramas por planta ( $\mathrm{g} / \mathrm{planta)}$ : foi obtida pela soma das pesagens de todos os frutos com padrão comercial colhidos em cada parcela; posteriormente, dividiu-se por quatro (número de plantas da área útil da parcela).

As análises de variâncias univariadas foram realizadas considerando-se como fontes de variações os efeitos de bloco, de genitores, de híbridos, do contraste genitores vs. híbridos e do erro experimental.

Para se avaliar a confiabilidade dos valores fenotípicos médios em representar os valores genotípicos, foi estimado o coeficiente de determinação genotípica $\left(\hat{H}^{2}\right)$, cuja expressão é

$$
\hat{H}^{2}=\left[\hat{\Phi}_{g} / \hat{\sigma}_{P}^{2}\right] \times 100
$$

em que

$$
\begin{aligned}
\hat{\Phi}_{8}= & \text { estimativa do componente quadrático associado aos efeitos } \\
& \text { genotípicos, para modelos fixos; e } \\
\hat{\sigma_{P}^{2}}= & \text { estimativa da variância fenotípica. }
\end{aligned}
$$

A divergência genética entre genitores (Rao, 1952) foi estimada pela distância generalizada de Mahalanobis $\left(D^{2}\right)$, que é definida como:

$$
\mathrm{D}^{2}=\underset{\sim}{d} \mathrm{~W}^{-1} \underset{\sim}{d}
$$

em que

$\underset{\sim}{d}$ : vetor de diferenças entre médias dos genitores para todos os $\mathrm{p}$ caracteres; 
$\underset{\sim}{d}$ : transposto;

$W$ : matriz $p \times p$ de variâncias e covariâncias residuais.

Para delimitação dos grupos de similaridade, adotou-se a técnica conglomerativa de Tocher, conforme recomendado por Rao (1952).

Para testar a eficiência da predição do comportamento dos híbridos a partir da divergência genética entre genitores, foram utilizados três métodos: 1) Coeficientes de correlação de Pearson $\left(r_{P}\right)$ e de Spearman $\left(r_{s}\right)$ (Steel et al., 1997); 2) Agrupamento dos genitores em classes de cruzamentos divergentes (CD) (Arunachalan \& Bandyopadhay, 1984); e 3) Classificação dupla.

Método 1 - foram estimados os coeficientes de correlação de Pearson e Spearman entre as estimativas da distância generalizada de Mahalanobis $\left(D^{2}\right)$, entre pares de genitores, e as médias dos híbridos respectivos, para os vários caracteres estudados (Steel et al., 1997). Este método é considerado eficiente se os coeficientes de correlação de $D^{2}$ entre os genitores e as médias dos híbridos forem estatisticamente significativos, podendo, portanto, ser utilizados na seleção de genitores para serem utilizados em cruzamentos.

Método 2 - conforme Arunachalam \& Bandyopadhyay (1984), foram calculados a média $(\mathrm{m})$ e o desvio-padrão $(\mathrm{s})$ dos valores de divergência $\left(D^{2}\right)$ entre os genitores para os caracteres analisados. As classes de divergência (CD) foram definidas como se segue: $C D 1: D^{2} \geq m+s$; $C D 2$ : $m+s>D^{2} \geq m$; CD3: $m>D^{2} \geq m-s ;$ e CD4: $D^{2}<m-s$. Os cruzamentos foram distribuídos nas diferentes classes, segundo a divergência entre os genitores. Neste método, a classificação é considerada satisfatória se as classes CD2 e CD3 contiverem os cruzamentos com melhores desempenhos.

Método 3 - método da classificação dupla, que consiste em:

a) Fazer a classificação das estimativas das médias dos genitores para todos os caracteres analisados. Isto consiste em classificar os genitores, em relação a cada um dos caracteres, em ordem crescente favorável ao melhoramento e 
somar os valores dos postos da classificação dos mesmos (Steel et al., 1997; Huehn, 1990a,b). Para o presente trabalho, buscou-se aumentar o valor de todos os caracteres estudados. Os melhores genitores foram classificados nas posições mais altas, com relação a cada caráter, e, dessa forma, apresentaram as maiores somas de postos de classificação.

b) Selecionar os genitores com maiores somas de valores de postos de classificação, descartando-se aqueles cujas somas de valores de postos de classificação sejam pequenas, em relação aos demais.

c) A partir do genitor com maior valor na soma de postos de classificação das médias, fazer a classificação com base na estatística $D^{2}$ de Mahalanobis, buscando-se o genitor que apresente a maior divergência genética com este. Assim, seleciona-se o cruzamento a ser feito.

A eficiência deste método é avaliada em função da posição do híbrido obtido no cruzamento selecionado, em relação aos demais.

Para efeito de comparação, foram incluídos os híbridos 'Nápoli' e 'Super F100'. Em todas as análises foi utilizado o programa GENES (Cruz, 1997).

\subsection{Resultados e discussão}

Observaram-se diferenças significativas entre genitores $(P<0,01)$ para todos os caracteres analisados (Tabela 1). Essa constatação indica possibilidade de discriminação das melhores combinações híbridas, feitas com base em divergência genética. Quanto aos híbridos, somente as diferenças relacionadas ao caráter $P R O D$ não foram significativas. Em razão disso, este caráter não foi considerado no cálculo da soma de postos de classificação para híbridos (Tabela 4).

Em relação a todos os caracteres analisados (Tabela 1), detectaram-se boa precisão experimental $\left(\mathrm{CV}_{\mathrm{e}}\right.$. inferior a $\left.16 \%\right)$ e coeficiente de 
determinação genotípica $\left(\hat{H}^{2}\right.$ ) acima de $80 \%$, indicando alta confiabilidade dos valores fenotípicos em representar os valores genotípicos.

Analisando as Tabelas 2 e 3, em relação à distância genética $\left(D^{2}\right)$, observa-se que os genitores 1 (PI 206472) e 3 ('Campineira') foram os mais similares $\left(D^{2}=4,58\right)$ e 1 (PI 206472) e 2 ('Long Green') os mais divergentes $\left(D^{2}=616,38\right)$. A identificação de pares de genitores com alta divergência tem sido objeto de muitos programas de melhoramento relacionados à obtenção de híbridos, visando maximizar a heterose e aumentar a probabilidade de ocorrência de segregantes superiores em gerações avançadas (Cruz et al., 1994b), bem como garantir base genética ampla para o início do programa de melhoramento (Hallauer \& Miranda Filho, 1988).

Em relação à associação entre divergência genética dos genitores e desempenho dos híbridos, pelo método 1, observou-se (Tabela 2) que, para o caráter número médio de frutos por planta (NMFP), as correlações de Pearson e de Spearman apresentaram associações significativamente positivas $(P<0,05)$. Assim, à medida que se aumenta o valor de $D^{2}$ entre os genitores, aumenta-se também o número de frutos do híbrido resultante do cruzamento dos mesmos.

Quanto aos caracteres CMF, DMF e PMF (Tabela 2), as correlações entre $D^{2}$ e o desempenho dos híbridos foram consideradas estatisticamente nulas. Segundo Ghaderi et al. (1984), correlações nulas podem ser explicadas pela existência de dominância bidirecional, em função do cancelamento dos desvios de dominância positivos pelos negativos, e vice-versa, entre os genitores. Segundo Cruz \& Vencovsky (1989) a dominância bidirecional é interpretada a partir dos sinais das estimativas de $s_{i l}$, onde valores positivos indicam a presença de genes dominantes que tendem a reduzir a expressão do caráter, enquanto que valores negativos indicam a presença de genes dominantes que tendem a aumentar a expressão do caráter. Tal fato pode ser observado na tabela 4 capítulo II. 
Tabela 1. Resumo das análises univariadas de variância de cinco caracteres relativos à produção de frutos por planta, em berinjela. ESALQ/USP, Piracicaba, SP.

\begin{tabular}{lcccccc}
\hline & & \multicolumn{5}{c}{ Q.M. } \\
\cline { 3 - 7 } FV & GL & CMF $^{1}$ & \multicolumn{1}{c}{ DMF $^{2}$} & PMF $^{3}$ & NMFP $^{4}$ & PROD $^{5}$ \\
\hline Blocos & 2 & 1,29 & 0,03 & 269,16 & 9,68 & 177565,82 \\
Tratamentos & 9 & $9,71^{\star \star}$ & $7,49^{\star \star}$ & $22734,01^{\star \star}$ & $178,80^{\star \star}$ & $883341,42^{\star \star}$ \\
Genitores(G) & 4 & $15,21^{\star \star}$ & $11,65^{\star \star}$ & $33475,70^{\star \star}$ & $327,98^{\star \star}$ & $1274289,10^{\star \star}$ \\
Hibridos (H) & 4 & $5,21^{\star \star}$ & $5,20^{\star \star}$ & $17301,85^{\star \star}$ & $65,11^{\star \star}$ & 436657,87 \\
G vs H & 1 & $5,78^{\star \star}$ & $0,01^{\text {ns }}$ & $1495,87^{\star}$ & $36,84^{\star}$ & $1106284,90^{\star \star}$ \\
Resíduo & 18 & 0,55 & 0,09 & 300,99 & 6,41 & 163326,02 \\
\hline Média & & 13,91 & 6,25 & 190,95 & 16,28 & 2529,06 \\
\hline C.V.(\%) & 5,32 & 4,88 & 9,09 & 8,59 & 15,98 \\
$\hat{H}^{2}(\%)$ & & 94,35 & 98,75 & 98,67 & 96,41 & 81,51 \\
\hline
\end{tabular}

*** *: $P<0,01$ e $P<0,05$, respectivamente.

1 'CMF: comprimento médio de fruto; ${ }^{2} \mathrm{DMF}$ : diâmetro médio de fruto; ${ }^{3} \mathrm{PMF}$ : peso médio de fruto; ${ }^{4}$ NMFP: número médio de frutos por planta; ${ }^{5} \mathrm{PROD}$ : produção total de frutos/planta.

Foi observada correlação negativa (Tabela 2) entre a divergência entre genitores $\left(D^{2}\right)$ e 0 desempenho dos híbridos para o caráter PROD $\left(r_{P}=-0,687, P<0,05\right)$, demonstrando associação linear inversa. Dessa forma, à medida que se aumenta a estimativa de $D^{2}$ entre genitores, tende-se a reduzir a produção de frutos do híbrido. Esse fato pode ser observado em relação aos genitores 1 e 2, os mais divergentes (Tabela 2), cujo híbrido apresentou estimativa menor para o caráter PROD que a do híbrido entre os genitores $1 \mathrm{e}$ 3, os mais similares (Tabela 2). 
Tabela 2. Estimativas da divergência genética entre pares de genitores $\left(D^{2}\right)$, das médias dos hibridos referentes a cinco caracteres relacionados à produção de frutos, das correlações de Pearson $\left(r_{p}\right)$ e Spearman $\left(r_{s}\right)$ entre $D^{2} \mathrm{e}$ as médias dos hibridos, para estes caracteres. ESALQ/USP, Piracicaba, SP.

\begin{tabular}{|c|c|c|c|c|c|c|}
\hline Hibridos $^{a}$ & $\mathrm{D}^{2}$ & $\mathrm{CMF}^{1}$ & $\mathrm{DMF}^{2}$ & $\mathrm{PMF}^{3}$ & NMFP $^{4}$ & PROD $^{5}$ \\
\hline $.1 \times 2$ & 616,38 & 13,45 & 4,96 & 130,82 & 22,79 & 2581,04 \\
\hline$+1 \times 3$ & 4,58 & 14,16 & 7,41 & 265,77 & 12,25 & 3253,33 \\
\hline$+1 \times 4$ & 387,27 & 16,05 & 6,61 & 220,29 & 12,58 & 2762,36 \\
\hline$\bullet 1 \times 5$ & 129,90 & 14,69 & 6,36 & 194,64 & 15,85 & 3000,52 \\
\hline $.2 \times 3$ & 555,26 & 13,34 & 5,20 & 138,70 & 21,34 & 2322,19 \\
\hline$+2 \times 4$ & 424,45 & 13,26 & 4,66 & 117,99 & 21,00 & 2472,42 \\
\hline$+2 \times 5$ & 236,97 & 12,96 & 5,06 & 117,08 & 19,33 & 2256,48 \\
\hline$\cdot 3 \times 4$ & 374,22 & 14,45 & 7,61 & 264,63 & 9,19 & 2381,25 \\
\hline$+3 \times 5$ & 104,40 & 15,30 & 7,48 & 268,92 & 10,66 & 2860,83 \\
\hline$\bullet 4 \times 5$ & 368,76 & 13,58 & 7,11 & 225,96 & 12,18 & 2360,26 \\
\hline c'Nápoli' & & 15,81 & 7,24 & 252,35 & 9,83 & 2482,91 \\
\hline 'Super F100' & & 15,48 & 7,12 & 236,33 & 10,83 & 2549,16 \\
\hline$r_{P}$ & & $-0,35^{n s}$ & $-0,58^{\text {ns }}$ & $-0,57^{n s}$ & $0,71^{*}$ & $-0,69^{*}$ \\
\hline$r_{s}$ & & $-0,37^{\text {ns }}$ & $-0,59^{\text {ns }}$ & $-0,57^{\text {ns }}$ & $0,64^{*}$ & $-0,48^{\mathrm{ns}}$ \\
\hline
\end{tabular}

${ }^{*} \mathrm{P}<0,05{ }^{\text {ns }}$ - não-significativo.

a 1 - PI 206472; 2 - 'Long Green'; 3 - 'Campineira'; 4 - 'Florida Market'; 5 - 'E-22';

1 CMF: comprimento médio de fruto; ${ }^{2} \mathrm{DMF}$ : diâmetro médio de fruto; ${ }^{3}$ PMF: peso médio de fruto; ${ }^{4}$ NMFP: número médio de frutos por planta; ${ }^{5}$ PROD: produção total de fruto/planta.

-híbrido predito;

thíbrido analisado; e

${ }^{c}$ híbrido comercial 
Tabela 3. Grupos de similaridade entre cinco genitores de berinjela estabelecidos pelo método de Tocher, a partir das distâncias generalizadas de Mahalanobis $\left(D^{2}\right)$. ESALQ/USP, Piracicaba, SP.

\begin{tabular}{cl}
\hline Grupos & \multicolumn{1}{c}{ Genitores } \\
\hline I & $1-$ PI 206472; 3 - 'Campineira e 5 - 'E-22' \\
II & 4 - 'Florida Market' \\
III & 2 - 'Long Green' \\
\hline
\end{tabular}

Estimativas de correlação negativa entre divergência dos genitores e desempenho dos híbridos foram observadas por Ghaderi et al. (1984) para o caráter número de dias para o florescimento em feijão (Phaseolus. vulgaris L.) e em fava (Vicia fava L.). De acordo com estes autores, a ocorrência de associação negativa implica existência de desvios de dominância negativos, ou seja, a presença de genes dominantes cujas expressões tendem a reduzir as estimativas do caráter. Assim, à medida que se aumenta a estimativa de $D^{2}$ entre os genitores, aumenta-se também a freqüência destes genes $e_{1}$ consequentemente reduz-se a expressão do caráter.

Para estabelecer as classes de cruzamentos divergentes (CD), conforme Arunachalam \& Bandyopadhyay (1984), método 2, calculou-se a divergência genética média $(m)$ entre os pares de genitores, cujo valor foi 320,22 e o desvio-padrão (s) igual a 198,03 (Tabela 2). Os cruzamentos foram separados nas seguintes classes:

$\operatorname{CD1}\left(D^{2} \geq m+s\right): D^{2} \geq 518,25=1 \times 2$ e $2 \times 3$;

CD2 $\left(m+s>D^{2} \geq m\right): 518,25>D^{2} \geq 320,22=1 \times 4,2 \times 4,3 \times 4$ e $4 \times 5$;

CD3 $\left(m>D^{2} \geq m-s\right): 320,22>D^{2} \geq 122,19=2 \times 5,1 \times 5$; e

$\operatorname{CD} 4\left(D^{2} \leq m-s\right): D^{2} \leq 122,19=1 \times 3,1 \times 5$ e $3 \times 5$.

Segundo o método 2 , as classes CD2 e CD3 são as que apresentam maior freqüência de cruzamentos com bom desempenho (Arunachalan \& Bandyopadhyay, 1984). Neste estudo, estas classes foram 
representadas pelos cruzamentos $1 \times 4 ; 2 \times 4 ; 3 \times 4 ; 4 \times 5 ; 2 \times 5$ e $1 \times 5$, os quais ocuparam as seguintes posições na soma valores de postos de classificação: segunda, oitava, terceira, quinta, nona e quarta, respectivamente (Tabela 4). O híbrido $3 \times 4$ ('Campineira $\times$ "Florida Market') que ocupou a terceira posição, já foi explorado comercialmente com o nome de híbrido 'F-100'.

Concluiu-se que o método 2 foi eficiente, pois, dentre seis cruzamentos selecionados, dois produziram híbridos que ocuparam as primeiras posições na soma de valores de postos de classificação.

Em relação ao método 3 , da classificação dupla, observou-se que o genitor 1 (PI 206472) apresentou bom desempenho para todos os caracteres analisados (Tabela 5), ocupando a primeira posição na soma de postos da classificação das médias. Esse fato, segundo Lal \& Pathak (1974), evidencia alta capacidade geral de combinação, o que pode ser confirmado pela soma de valores de postos de classificação das estimativas da capacidade geral de combinação dos genitores analisados (Tabela 6). Portanto, o genitor 1 (PI 206472) tem grande concentração de alelos favoráveis para os caracteres estudados (Vencovsky, 1970).

Observou-se que o genitor 3 ('Campineira') ocupou a segunda posição (Tabela 5) e os genitores 4 ('Florida Market') e 5 ('E-22') ocuparam a terceira, na soma de valores de postos da classificação das estimativas das médias, sendo, portanto, escolhidos para a fase seguinte do método. Por outro lado, o genitor 2 ('Long Green') obteve a quinta classificação para quatro dos cinco caracteres analisados e foi, consequentemente, descartado, pois sua soma de postos da classificação foi muito baixa em relação aos demais genitores (Tabela 5). 
Tabela 4. Comparação das estimativas das médias de cinco caracteres, de híbridos preditos e analisados, por meio da soma de postos de classificação em berinjela. ESALQ/USP, Piracicaba, SP.

\begin{tabular}{|c|c|c|c|c|c|c|c|c|c|c|}
\hline \multirow{3}{*}{ Híbridos $\left({ }^{2}\right)$} & \multicolumn{9}{|c|}{ Caracteres ( $\left.{ }^{1}\right)$} & \multirow{3}{*}{$\begin{array}{c}\text { Soma } \\
\text { de } \\
\text { Postos }\end{array}$} \\
\hline & \multicolumn{2}{|c|}{ CMF } & \multicolumn{2}{|c|}{ DMF } & \multicolumn{2}{|c|}{ PMF } & \multicolumn{2}{|c|}{ NMF } & PROD & \\
\hline & média & clas. * & média & clas. & média & clas. & média & clas. & média & \\
\hline $.1 \times 23^{3}$ & 13,45 & 04 & 4,96 & 02 & 130,82 & 03 & 22,79 & 10 & 2581,04 & 19 \\
\hline$+1 \times 3\left(^{4}\right)$ & 14,16 & 06 & 7,41 & 08 & 265,77 & 09 & 12,25 & 04 & 3253,33 & 27 \\
\hline$+1 \times 4$ & 16,05 & 10 & 6,61 & 06 & 220,29 & 06 & 12,58 & 05 & 2762,36 & 27 \\
\hline $.1 \times 5$ & 14,69 & 08 & 6,36 & 05 & 194,64 & 05 & 15,85 & 06 & 3000,52 & 24 \\
\hline $.2 \times 3$ & 13,34 & 03 & 5,20 & 04 & 138,70 & 04 & 21,34 & 09 & 2322,19 & 20 \\
\hline$+2 \times 4$ & 13,26 & 02 & 4,66 & 01 & 117,99 & 02 & 21,00 & 08 & 2472,42 & 13 \\
\hline$+2 \times 5$ & 12,96 & 01 & 5,06 & 03 & 117,08 & 01 & 19,33 & 07 & 2256,48 & 12 \\
\hline $.3 \times 4$ & 14,45 & 07 & 7,61 & 10 & 264,63 & 08 & 9,19 & 01 & 2381,25 & 26 \\
\hline$+3 \times 5$ & 15,30 & 09 & 7,48 & 09 & 268,92 & 10 & 10,66 & 02 & 2860,83 & 30 \\
\hline $.4 \times 5$ & 13,58 & 05 & 7,11 & 07 & 225,96 & 07 & 12,18 & 03 & 2360,26 & 22 \\
\hline
\end{tabular}

(1) CMF: comprimento médio de frutos; DMF: diâmetro médio de frutos; PMF: peso médio de frutos; NMFP: número médio de frutos por planta; PROD: produção total de frutos por planta.

$\left(^{2}\right)$ 1: PI 206472; 2: 'Long Green'; 3: 'Campineira'; 4: 'Florida Market'; 5: “E-22'

(') $\bullet$ : hibrido predito.

(4)+: hibrido analisado.

$(5)$ : híbrido comercial.

* clas.: classificação.

Comparando as distâncias genéticas (Tabela 2) do genitor 1 (PI 206472), em relação aos genitores 3, 4 e 5, selecionou-se o genitor 4 ('Florida Market'), por ser o mais distante $\left(D^{2}=387,27\right)$. Observou-se que o hibrido $1 \times 4$ (Tabela 4) ocupou a segunda melhor posição na soma de postos de classificação das combinações híbridas analisadas e preditas. Assim, foi demonstrada a eficiência do método $3 \mathrm{em}$ selecionar cruzamentos cujos hibridos tenham bom desempenho, sem que para isto tenham que ser feitos os cruzamentos previamente. 
Tabela 5. Estimativas da média para cinco caracteres de cinco genitores de berinjela, as classificações destes e a soma de postos de classificação. ESALQ/USP, Piracicaba, SP.

\begin{tabular}{ccccccccccccc}
\hline \multirow{2}{*}{ Genitor } & \multicolumn{2}{c}{ CMF $^{1}$} & \multicolumn{2}{c}{ DMF $^{2}$} & \multicolumn{2}{c}{ PMF $^{3}$} & \multicolumn{2}{c}{ NMFP $^{4}$} & \multicolumn{2}{c}{ PROD $^{5} \begin{array}{c}\text { Soma } \\
\text { de } \\
\text { postos }\end{array}$} \\
\cline { 2 - 12 } & Média & clas. & média & clas. & média & clas. & média & clas. & média & clas. \\
\hline $\mathbf{1}^{2}$ & 15,63 & 04 & 6,77 & 04 & 227,42 & 04 & 13,667 & 03 & 3103,333 & 05 & 20 \\
2 & 10,54 & 01 & 3,65 & 01 & 49,78 & 01 & 32,833 & 05 & 1638,286 & 01 & 09 \\
3 & 15,80 & 05 & 6,39 & 03 & 191,75 & 03 & 13,583 & 02 & 2587,143 & 03 & 16 \\
4 & 12,26 & 02 & 9,04 & 05 & 328,38 & 05 & 5,083 & 01 & 1672,916 & 02 & 15 \\
5 & 13,12 & 03 & 5,47 & 02 & 122,13 & 02 & 21,750 & 04 & 2683,456 & 04 & 15 \\
\hline
\end{tabular}

${ }^{1} \mathrm{CMF}$ : comprimento médio de fruto; ${ }^{2} \mathrm{DMF}$ : diâmetro médio de fruto; ${ }^{3} \mathrm{PMF}$ : peso médio de fruto; ${ }^{4} \mathrm{NMFP}$ : número médio de frutos por planta; ${ }^{5} \mathrm{PROD}$ : produção total de frutos por planta.

a 1 - PI 206472; 2 - 'Long Green '; 3 - 'Campineira'; 4 - 'Florida Market'; 5 - 'E-22'.

clas.: classificação.

O híbrido 1 × 4 (PI 206472 x 'Florida Market'), quando comparado aos híbridos 'Nápoli' e 'Super F 100' (Tabela 2), apresentou estimativas superiores para os caracteres comprimento médio de fruto (CMF), número médio de frutos por planta (NMFP) e produção total de frutos por planta (PROD). Isto demonstra o grande potencial deste cruzamento para ser explorado comercialmente.

O método da classificação dupla foi desenvolvido buscando-se garantir o cruzamento de genitores com alta concentração de alelos favoráveis e que sejam complementares entre si, pois, ao selecionar genitores com boas posições na soma de postos da classificação das médias, seleciona-se genitores com altas estimativas de capacidade geral de combinação (Lal \& Pathak, 1974), o que é indicativo de grande concentração de alelos favoráveis (Vencovsky, 1970). Ao selecionar dentre estes o par cuja estimativa de divergência genética seja máxima, busca-se garantir a diferença de freqüência 
gênica entre os genitores a serem cruzados (Weir, 1996). Estas são algumas das possíveis razões para o bom desempenho do cruzamento escolhido.

Embora os métodos 2 e 3 tenham sido considerados eficientes, eles não selecionaram ou explicaram o híbrido $3 \times 5$ ('Campineira' $\times$ 'E-22'), que ocupou a primeira posição na soma de postos da classificação das médias (Tabela 4). Os genitores 3 e 5 foram classificados em segundo e terceiro lugar, respectivamente, na soma de postos de classificação das médias (Tabela 5), Comportamento semelhante pode ser observado em relação às estimativas de capacidade geral de combinação (Tabela 6); dessa forma, pode-se supor que estes genitores tenham grande concentração de alelos favoráveis. Embora a estimativa de $D^{2}$, entre os genitores 3 e 5 (Tabela 2), seja relativamente pequena, não justificando, portanto, efeitos heteróticos pronunciados para 0 hibrido resultante do cruzamento destes, estes genitores apresentam bom efeito de complementação gênica, pois, como pode ser observado na Tabela 4 do capítulo II, este cruzamento possui estimativas positivas de $s_{i j}$ para os caracteres CMF, DMF, PMF e PROD.

Pode-se concluir que 0 híbrido $3 \times 5$ ('Campineira'x 'E-22') apresentou 0 melhor desempenho dentre os hibridos analisados e preditos, pois, os genitores 3 e 5 associam grande concentração de alelos favoráveis e complementaridade destes alelos para os caracteres relacionados à produção de frutos em berinjela. 
Tabela 6. Estimativas dos efeitos da capacidade geral de combinação $\left(\hat{g_{i}}\right)$ para cinco caracteres de cinco genitores de berinjela, as classificações destes e a soma de postos de classificação. ESALQ/USP, Piracicaba, SP.

\begin{tabular}{|c|c|c|c|c|c|c|c|c|c|c|c|}
\hline \multirow[t]{2}{*}{ Genitor } & \multicolumn{2}{|c|}{$\mathrm{CMF}^{1}$} & \multicolumn{2}{|c|}{$\mathrm{DMF}^{2}$} & \multicolumn{2}{|c|}{$\mathrm{PMF}^{3}$} & \multicolumn{2}{|c|}{ NMFP $^{4}$} & \multicolumn{2}{|c|}{ PROD $^{5}$} & \multirow{2}{*}{$\begin{array}{c}\text { Soma } \\
\text { de } \\
\text { postos }\end{array}$} \\
\hline & $\hat{g_{i}}$ & clas.* & $\hat{g_{i}}$ & clas. & $\hat{g_{i}}$ & clas. & $\hat{g_{i}}$ & clas. & $\hat{g_{i}}$ & clas. & \\
\hline $1^{2}$ & 0,88 & 05 & 0,18 & 03 & 17,23 & 03 & $-0,80$ & 03 & 375,65 & 05 & 19 \\
\hline 2 & $-1,33$ & 01 & $-1,46$ & 01 & $-77,36$ & 01 & 7,94 & 05 & $-323,65$ & 01 & 09 \\
\hline 3 & 0,76 & 04 & 0,42 & 04 & 25,11 & 04 & $-1,97$ & 02 & 116,79 & 04 & 18 \\
\hline 4 & $-0,22$ & 02 & 0,93 & 05 & 48,56 & 05 & $-4,47$ & 01 & $-264,60$ & 02 & 15 \\
\hline 5 & $-0,09$ & 03 & $-0,07$ & 02 & $-13,54$ & 02 & $-0,70$ & 04 & 95,81 & 03 & 14 \\
\hline
\end{tabular}

${ }^{1} \mathrm{CMF}$ : comprimento médio de fruto; ${ }^{2} \mathrm{DMF}$ : diâmetro médio de fruto; ${ }^{3} \mathrm{PMF}$ : peso médio de fruto; ${ }^{4} \mathrm{NMFP}$ : número médio de frutos por planta; ${ }^{5} \mathrm{PROD}$ : produção total de frutos por planta.

a 1 - PI 206472; 2 - 'Long Green '; 3 - 'Campineira'; 4 - 'Florida Market'; 5 - 'E-22'.

* clas.: classificação. 


\section{CONCLUSŌES}

Analisando os três capítulos desta tese, podem-se obter as seguintes conclusões:

a) Em relação à estabilidade da divergência genética entre acessos (Capítulo I):

$\left.a_{1}\right)$ a diversidade genética entre um grupo de acessos pode ser estimada a partir de diferentes conjuntos de caracteres, obtidos em diferentes estádios do desenvolvimento, e a diversidade varia em relação a cada conjunto considerado. Assim, em relação aos caracteres vegetativos e reprodutivos, os acessos mais divergentes foram L4 ('Florida Market') e L 10 (PI 166995), enquanto L 4 e L 12 ('Indiana') foram os mais divergentes com base nos caracteres do estádio produtivo;

$a_{2}$ ) os caracteres do estádio vegetativo permitiram separar os acessos em dois grupos, os do estádio reprodutivo em quatro e os do estádio produtivo em seis grupos;

$a_{3}$ ) as estimativas de divergência entre os três estádios analisados foram positivamente correlacionadas, e a significância desta correlação reduz à medida que os estádios do desenvolvimento se distanciam;

$a_{4}$ ) é possível a utilização dos resultados do estádio reprodutivo, como indicativo do estádio produtivo, mas com redução no número de grupos formados; e

as) para programas de melhoramento, deve-se fazer a análise de divergência para caracteres relacionados aos objetivos do programa; e o estádio produtivo foi o de maior poder de discriminação. 
b) Quanto à análise combinatória (Capítulo II), concluiu-se que:

$b_{1}$ ) os efeitos gênicos aditivos predominaram na expressão de todos os caracteres analisados;

$b_{2}$ ) os cultivares 1 (PI 206472) e 3 ('Campineira') são os mais indicados para programas de melhoramento genético intrapopulacionais, em função das CGCs destes para os caracteres analisados; $e$

$b_{3}$ ) os cruzamentos $1 \times 3$ (PI $206472 \times$ 'Campineira'), 1 × 4 (PI $206472 \times$ 'Flórida Market'), 1 × 5 (PI 206472 × 'E-22') e $3 \times 5$ ('Campineira' x 'E-22') têm alto potencial para gerar híbridos economicamente superiores.

c) Quanto à comparação de métodos para a avaliação da associação entre divergência genética dos genitores e desempenho dos hibridos (Capitulo III), concluiu-se que:

$c_{1}$ ) com base no método baseado nas correlações de Pearson e Spearman, observou-se que a divergência $\left(D^{2}\right)$ mostrou estar linearmente associada ao desempenho médio dos híbridos para o caráter número médio de frutos por planta e inversamente relacionada para o caráter produção de total de frutos/planta (grama por planta):;

$c_{2}$ ) a utilização do método baseado na média e no desvio-padrão das estimativas de $D^{2}$ mostrou-se promissora, pois dois hibridos selecionados (PI 206472 x 'Florida Market' e 'Campineira' x 'Florida Market') que ocuparam a segunda e a terceira posição, respectivamente, na soma de postos de classificação das médias.dos hibridos; $\mathrm{e}$

$c_{3}$ ) o método da classificação dupla (soma de postos de classificação e $D^{2}$ ) foi considerado eficiente, pois selecionou o cruzamento PI 206472 x 'Florida Market', que obteve a segunda posição na soma de postos da classificação das médias dos hibridos, superando hibridos cultivados comercialmente. 


\section{REFERÊNCIAS BIBLIOGRÁFICAS}

AMARAL JÚNIOR, A.T. Análise dialélica de betacaroteno, vitamina c, sólidos solúveis e produção e variabilidade em cultivares de tomateiro (Lycopersicon esculentum Mill.) via RAPD. Viçosa, 1996. 198 p. Tese (Doutorado) - Universidade Federal de Viçosa.

AMARAL JÚNIOR, A.T.; CASALI, V.W.D.; SCAPIM, C.A.; SILVA, D.J.H.; CRUZ, C.D. Análise dialélica da capacidade combinatória de cultivares de tomateiro. Bragantia, v.55, n.1, p.67-73, 1996.

ARUNACHALAM, V Genetic distance in plant breeding. Indian Journal of Genetics and Plant Breeding, v.41, n.2, p.226-236, 1981.

ARUNACHALAM, V; BANDYOPADHYAY, A. Limits to genetic divergence for occurrence of heterosis-experimental evidence from crop plants. Indian Journal of Genetics and Plant Breeding, v.44, n.3, p.548-554, 1984.

AVATAR, R.; DASHORA, S.L.; SHARMA, R.K.; SHARMA, M.M. Analysis of genetic divergence in cumin (Cuminum cyminum L.). Indian Journal of Genetics and Plant Breeding, v.51, n.3, p.289 - 291, 1991. 
AWASTHI, C.P.; ABIDI, A.B.; DIXIT, J. Biochemical constituents of promising cultivars of brinjal. Indian Journal of Horticulture, v.44, n.3-4, p.245 249,1987 .

BERNARDO, R. Relationship between single-cross performance and molecular marker heterozygosity. Theoretical and Applied Genetics, v.83, n.5, p.628-634, 1992.

BERTHAUD, J. Strategies for conservation of genetic resources in relation with their utilization. Euphytica, v.96, n.1, p.1-12, 1997.

BHANDARI, M.M. Euclidean cluster analysis in moth bean over two different environments. International Journal of Tropical Agriculture, v.9, n.1, p. $21-24,1991$.

BOLETIM MENSAL CEAGESP, São Paulo, n.12, dez., 1994.

BUSSAB, W.O.; MIAZAKI, E.S.; ANDRADE, D.F. Introdução à análise de agrupamentos. São Paulo: Associação Brasileira de Estatística, 1990. $105 p$.

CAMUSSI, A. E.; OTTAVIANO, E.; CALINSK, T.; KACZMAREK, Z. Genetic distance based on quantitative traits. Genetics, n.111, p.945-965, 1985.

CARVALHO, L.P. Divergência genética e análise dialélica em Gossypium hirsutum L. var. latifolium Hutch. Viçosa, 1993. 203p. Tese (Doutorado) Universidade Federal de Viçosa. 
CHADHA, M.L.; HEDGE, R.K.; BAJAJ, K.L. Heterosis and combining ability studies of pigmentation in brinjal (Solanum melongena L.). Vegetable Science, v.15, n.1, p.64-71, 1988.

CHADHA, M.L.; HEGDE, R.K. Combining ability studies in brinjal. Indian Journal of Horticulture, v.46, n.1, p.44-52,1989.

CLEMENTS, J. C.; COWLING, W.A. Pattems of morphological diversity in relation to geographical origins of wild Lupinus angustifolius from the Aegean region. Genetic Resources and Crop Evolution, v.41, n.2, p.109122, 1994.

COSTA, C.P.; PINTO, C.A.B.P. Melhoramento de hortaliças. Piracicaba: ESALQ/USP, 1977. 315p.

CRESS, C.E. Heterosis of the hybrid related to gene frequency differences between two populations. Genetics, v.53, n.2, p.269-274, 1966.

CRUZ, C.D. Aplicação de algumas técnicas multivariadas no melhoramento de plantas. Piracicaba, 1990, 188p. Tese (Doutorado) - Escola Superior de Agricultura "Luiz de Queiroz", Universidade de São Paulo.

CRUZ, C.D. Programa Genes; aplicativo computacional em genética e estatística. Viçosa: UFV, 1997. 442p.

CRUZ, C.D.; VENCOVSKY, R. Comparação de alguns métodos de análise dialélica. Revista Brasileira de Genética, v.12, n.2, p.425-438, 1989.

CRUZ, C.D. ; REGAZZI, A. J. Modelos biométricos aplicados ao melhoramento genético. Viçosa: UFV, 1994. 390p. 
CRUZ, C.D.; CARVALHO, S.P.; VENCOVSKY, R. Estudos sobre divergência genética. I. Fatores que afetam a predição do comportamento de hibridos Revista Ceres, v.41, n.234, p.178-182, 1994a.

CRUZ, C.D.; CARVALHO, S.P.; VENCOVSKY, R. Estudos sobre divergência genética. II. Eficiência da predição do comportamento de híbridos com base na divergência de progenitores. Revista Ceres, v.41, n.234, p.183-190, 1994b.

CRUZ, C.D.; VENCOVSKY, R.; CARVALHO, S.P. Estudos sobre divergência genética. III. Comparação de técnicas multivariadas. Revista Ceres, v.41, n.234, p.191-201, 1994c.

DANTAS, A. C. V. L. Cruzamento dialélico parcial circulante para avaliação de linhagens de milho (Zea mays L.) e predição de híbridos. Piracicaba, 1988. 153p. Dissertação (Mestrado) - Escola de Agricultura "Luiz de Queiroz", Universidade de São Paulo.

DIAS, J.S.; MONTEIRO, A.A.; LIMA, M.B. Numerical taxonomy of Portuguese Tronchuda cabbage and Galega Kale landraces using morphological characters. Euphytica, v.69, n.1-2, p.51-68, 1993.

DIAS, L.A.S. Análises multidimensionais. In: ALFENAS, A.C.(Ed.) Eletroforese de isoenzimas e proteínas afins: fundamentos e aplicações em plantas e microrganismos. Viçosa: UFV, 1998. cap. 9, p.405-476.

DIAS, L.A.S.; KAGEYAMA, P. Temporal stability of multivariate genetic divergence in cacao (Theobroma cacao L.) in Southern Bahia conditions. Euphytica, v.93, n.3, p.181-187, 1997 a. 
DIAS, L.A.S.; KAGEYAMA, P. Multivariate genetic divergence and hybrid performance of cacao (Theobroma cacao L.). Brazilian Journal of Genetics, v.20, n.1, p.63-70, 1997b.

DIERS, B.W.; McVETTY, P.B.E.; OSBORN, T.C. Relationship between heterosis and genetic distance based on restriction fragment length polymorphism markers in Oilseed Rape (Brassica napus L.). Crop Science, v.36, n.1, p.79-83, 1996.

DHILLON, B.S.; SINGH, J. Evaluation os extended triangular partial diallel crosses. Zeitschrift Pflzucht, v.80, n.2, p.311-319, 1978.

ESQUIVEL, $M$; BARRIOS, $M$; WALON, L.; HAMMER, $K$; KNUPFFER, $H$. Arachis In: HAMMER, K.; ESQUIVEL,M., (Ed.) Origin, evolution and diversity of Cuban plant genetic resources. Gatersleben: Institut fur Pflanzengenetik und Kulturpflanzenforschung, 1994. p.600-612

FALCONER, D.S.; MACKAY, T.F.C. Introduction to quantitative genetics. 4. ed. Essex: Longman Group, 1996. 464p.

FERREIRA, D.F. Métodos de avaliação da divergência genética em milho e suas relações com os cruzamentos dialélicos. Lavras, 1993. 72p. Dissertação (Mestrado) - Escola Superior de Agricultura de Lavras.

FERREIRA, M.E.; GRATTAPAGLIA, D. Introdução ao uso de marcadores RAPD e RFLP em análise genética. Brasília: EMBRAPA-CENARGEN, 1995. 220p.

FILGUEIRA, F.A.R. Manual de olericultura: cultura e comercialização de hortaliças. 2. ed. São Paulo: Agronômica Ceres, 1982. v.2, 357p. 
GARDNER, C.O.; EBERHART, S.A. Analysis and interpretation of the variety cross diallel and related populations. Biometrics, v.22, n.18, p.439-452, 1966.

GHADERI, A.; ADAMS, M.W.; NASSIB, A.M. Relationship between genetic distance and heterosis for yield and morphological traits in dry edible bean. Crop Science, v.24, n.1, p.37-42, 1984.

GIZLICE, Z.; CARTER, T.E. J.R.; BURTON, J.W. Genetic diversity in North American soybean: II. Prediction of heterosis in $F_{2}$ populations of southern founding stock using genetic similarity measures. Crop Science, v.33, n.3, p.620-626, 1993.

GONÇALVES, P. Esquema circulante de cruzamentos para avaliação de linhagens de milho (Zea mays L.) ao nível interpopulacional. Piracicaba, 1987. 140 p. Tese (Doutorado) - Escola Superior de Agricultura "Luiz de Queiroz", Universidade de São Paulo.

GOUDER, R.A.; YEOMANS, K.A. The use of clusters analysis for stratification. Applied Statistics, v.22, n.2, p.213-219, 1973.

GRIFFING, B. Concept of general and specific combining ability in relation to diallel crossing systems. Australian Journal of Biological Sciences, v.9, n.4, p.463-493, 1956.

GUPTA, V.P.; SEKHON, M.S.; SATIJA, D.R. Studies on genetic diversity, heterosis and combining ability in Indian mustard (Brassica juncea L. (CZEN e COSS). Indian Journal of Genetics and Plant Breeding, v.51, n.4, p.448-453, 1991. 
HALLAUER, S.R.; MIRANDA FILHO, J.B. Quantitative genetics in maize breeding. 2.ed. Ames: lowa State University Press, 1988, 468p.

HARLAN, R.J. Geographic patterns of variation in some cultivated plants. The Journal of Heredity, v.66, n.4, p.182-191. 1975.

HARRIS, R.J. A primer of multivariate statistics. New York: Academic Press, 1975. p.332.

HAYMAN, B.I. The analysis of variance of diallel tables. Biometrics, v.10, n.40, p.235-244, 1954a.

HAYMAN, B.I. The theory and analysis of diallel crosses. Genetics, v.45, n.6, p.789-790, 1954b.

HOLBROOK, C.C.; ANDERSON, W.F.; PITTMAN, R.N. Selection of a core collection of Peanut. Crop Science, v.33, p.859-861, 1993.

HUEHN, M. Nonparametric measures of phenotypic stability. Part 1 : theory. Euphytica, v.47, n.2, p.189-194, 1990a.

HUEHN, M. Nonparametric measures of phenotypic stability. Part 2 : applications. Euphytica, v.47, n.2, p.195-201, 1990b

IBPGR. Descriptors for eggplant/descripteurs pour l'aubergine. Roma: IBPGR, 1990. 60p.

INGALE, B.V.; PATIL, S.J. Diallel analysis of fruit characteristics in eggplant. PKV Research Journal, v.21, n.1, p. 30-34, 1997. 
JOHNSON, R.A.; WICHERN, D.W. Applied multivariate statistics analysis. New Jersey: Prentice-Hall, 1982. 320p.

KARIHALOO, J.L.; BRUNER, S.; GOTTLIED, L.D. Random amplified polymorphic DNA variation in the eggplant, Solanum melongena L. (Solanaceae). Theoretical and Applied Genetics, v.90, n.6, p.767-770, 1995.

KEMPTHORNE, O. The theory of the diallel cross. Genetics, v.41, n.4, p. 451459, 1956.

KEMPTHORNE, O. ; CURNOW, R.N. The partial diallel cross. Biometrics, v. 17, n.2, p. 229-250, 1961.

LAL, S.; PATHAK, M.M. Combining ability in brinjal. Indian Journal of Genetics and Plant Breeding, v.34, n.3, p.395-399, 1974.

LOISELLE, F.; TAI, G.C.C.; TARN,T.R.; CHRISTIE, B.R. The use of multivariate analyses to eliminate redundant variables when evaluating potatoes for chip quality. Plant Breeding, v.103, n.2, p.153-162,1989.

MAHALANOBIS, P.C. On the generalized distance in statistic. Proceeding National Institucion Science, v.2, n.19, p.49-55, 1936.

MALUF, W.R.; FERREIRA, P.E. Genetic divergence in tomatoes and its relationship with heterosis for yield in $F_{1}$ 's hybrids. Revista Brasileira de Genética, v.6, n.3, p.453-460, 1983. 
MANJARREZ-SANDOVAL, P.; CARTER JÚNIOR, T.E.; WEBB, D.M.; BURTON, J.W. Heterosis in soybean and its prediction by genetic similarity measures. Crop Science, v. 37, n.5, p.1443-1452, 1997.

MARDIA, K.V.; KENT, J.T.; BIBBY, J.M. Multivariate analysis. London: Academic Press, 1979. 521p.

MELO, P.C.T. Heterose e capacidade combinatória em um cruzamento dialélico parcial entre seis cultivares de tomate (Lycopersicon esculentum Mill.). Piracicaba, 1987. 110p. Tese (Doutorado) - Escola Superior de Agricultura 'Luiz de Queiroz", Universidade de São Paulo.

MIRANDA FILHO, J.B.; GERALDI, I. O. A adapted model for the analysis of partial diallel crosses. Revista Brasileira de Genética, v.4, n.7, p.677-688, 1984.

MIRANDA FILHO, J.B.; VIÉGAS, P.G. Milho híbrido. In: PATERNIANI, E.; VIÉGAS, G.P. (Ed.) Melhoramento e produção de milho. 2.ed. Campinas: Fundação Cargil, 1987. cap. 7, p.275-340.

MIRANDA, J.E.C.; CRUZ, C.D.; COSTA, C.P. Predição do comportamento de híbridos de pimentão (Capsicum annum L.) pela divergência dos genitores. Revista Brasileira de Genética, v.11, n.9, p.929-937, 1988.

MURTY, B.R.; ARUNACHALAN, V.; ANAND, I.J. Effect of enviroment on the genetic divergence among some populations of linseed. Indian Journal of Genetics and Plant Breeding, v.33, n.3, p.304-313, 1973. 
NAIDU, N.V.; SATYANARAYANA, A. Studies on genetic divergence over environments in mungbean (Vigna radiata L. Wilczek). Indian Journal of Genetics and Plant Breeding, v.51, n.4, p.454-460, 1991.

NARENDRA, K.; RAM, H.H. Components of genetic variation in eggplant. Crop-Improvement, v.16, n.1, p.92-94, 1989.

NODA, H. Critérios de avaliação de progênies de irmãos germanos interpopulacionais em berinjela (Solanum melongena L.). Piracicaba, 1980. 91p. Dissertação (Mestrado) - Escola Superior de Agricultura "Luiz de Queiroz", Universidade de São Paulo.

OLIVEIRA JÚNIOR, A. Metodologias de análise de dialelos circulante e de meia-tabela desbalanceados e correlações inter e intra-populacionais: exemplo para a cultura do feijão (Phaseolus vulgaris L.). Viçosa, 1995. p.132. Dissertação (Mestrado) - Universidade Federal de Viçosa.

OLIVEIRA, V.R. Diversidade genética em pimentão (Capsicum annum L.) e controle gênico da tolerância ao baixo teor de fósforo no solo. Viçosa, 1997. p.102. Tese (Doutorado) - Universidade Federal de Viçosa.

PACHECO, C.A.P. Associação das metodologias de análise dialélica de Griffing e de análise de adaptabilidade e estabilidade de Eberhart e Russel. Viçosa, 1997. 118p. Tese (Doutorado) - Universidade Federal de Viçosa.

PADMANABHAM, V.; JAGADISH, C.A. Combinig ability studies on yield potential of round fruited brinjal (Solanum melongena L.). Indian Journal of Genetics and Plant Breeding, v.56, n.2, p.141-146, 1996. 
PATEL, J.A.; GODHANI, P.R.; FOUGAT, R.S. Combinig ability analysis in brinjal (Solanum melongena L.). Gujarat Agricultural University Research Journal, v.19, n.2, p.72-77, 1994.

PIMENTEL GOMES, F. Curso de estatística experimental. 13.ed. Piracicaba: Nobel, 1990. 468p.

PLEKHANOVA, M.N.; ROSTOVA, N.S. Analysis of variation in morphological, anatomical and biochemical characteristics of Lonicera subsection Caeruleae (Caprifoliaceae) by using the principal components method. Botanicheskii-Zhurnal, v.79, n.2, p.45-64,1994.

RAMALHO, M.A.P.; SANTO, J.B.; PINTO, C.A.B.P. Genética na agropecuária. 3.ed. São Paulo: Globo, 1989. 359p.

RAMALHO, M.A. P.; SANTOS, J.B.; ZIMMERMAN, M.J.O. Genética quantitativa aplicada em plantas autógamas: aplicação ao melhoramento do feijoeiro. Goiânia: UFG, 1993. 217p.

RAO, R.C. Advanced statiscal methods in biometrical research. New York: John Wiley \& Sons, 1952. 390p.

RASHID, M.A.; MONDAL, S.N.; AHMED, M.S; AHMAD, S.; SEN, D.K. Genetic variability, combining ability estimates and hybrid vigour in eggplant (Solanum melongena L.). Thai Journal of Agricultural Science, v.21, n.1, p.51-61,1988.

RUSSEL, W. A.; EBERHART, S.A. Hybrid performance of select maize lines from reciprocal recurrent selection and testcross selection programs. Crop Science, v. 15, n.1, p.1-4, 1975. 
SAGHAI MAROOF, M.A.; YANG, G.P.; ZHANG, Q.; GRAVOIS, K.A. Correlation between molecular marker distance and hybrid performance in U.S. Southern long grain rice. Crop Science, v.37, n.1, p.150-153, 1997.

SEARLE, S.R. Linear models. New York: John Wiley \& Sons. 1971. 532p.

SINGH, N.D.; MITAL, R.K. Genetics of yield and its components in eggplant (Solanum melongena L.). Indian Journal of Agricultural Sciences, v. 58, n.5, p.402-403, 1988.

SINGH, B.; KUMAR, N. Studies on hybrid vigour and combining ability in brinjal (Solanum melongena L.). Vegetable Science, v.15, n.1, p.72-78, 1988.

SINGH, D. The relative importance of characters affecting genetic divergence. Indian Journal of Genetics and Plant Breeding. v.41, n.2, p.237-245, 1981.

SINGH, R.K.; CHAUDARY, B.D. Biometrical methods in quantitative genetic analysis. New Delhi: Kalyani Publishers, 1979. 304p.

SINGH, T.H.; GILL, S.S. Genetic diversity in upland cotton under different environments. Indian Journal of Genetics and Plant Breeding, v.44, n.3, p. $506-513,1984$.

SINGH, Y.V.; RAM, H.H.; SINGH, K.; JAIDEEP, B.; SINGH, K. ; BHARGAVA, J. Genetic diversity in brinjal (Solanum melongena L.). Recent Horticulture, v.2, n.2, p.78-83, 1995.

SNEATH, P.H.; SOKAL, R.R. Numerical taxonomy: the principles and practice of numerical classification. W.H. Freeman. 1973. 573p. 
SPAGNOLETTI ZEULLI, P.L.; QUALSET, C.O. Evaluation of five strategies for obtaining a core subset from a large genetic resource collection of durum wheat. Theoretical and Applied Genetics, v.87, n.3, p.295-304, 1993.

SPOONER, D.M.; BERG, R.G VAN DEN.; VAN DEN BERG, R.G. Species limits and hypotheses of hybridization of Solanum berthaultii Hawkes and $S$. tarijense Hawkes: morphological data. Taxon, v.41, n.4, p.685-700, 1992.

SPRAGUE, G.F.; TATUM, L. A. General vs specific combining ability in single crosses of corn. Journal of the American Society of Agronomy. v.34, n.63, p.923-932, 1942.

STANTON, M.A.; STEWART, J.M.; PERCIVAL, A.E.; WENDEL, J.F. Morphological diversity and relationships in the A-genome cottons, Gossypium arboreum and G. herbaceum. Crop Science, v.34, n.2, p.519$527,1994$.

STEEL, R.G.D.; TORRIE, J.H.; DICKEY, D.A. Principles and procedures of statistics: a biometrical approach. 3.ed. New York: McGraw-Hill, 1997. $666 p$.

TAMBE, T.B.; RANE, D.A.; KALE, P.N. Diversity studies in brinjal (Solanum melongena L.). Maharastra Journal of Horticulture, v.7, n.1, p.81-87, 1993.

TCACENCO, F.A.; LANCE, G.N. Selection of morphological traits for characterisation of elephant grass accessions. Tropical Grasslands, v.26, n.3, p.145-155, 1992. 
VALOIS, A.C.C.; SALOMÃO, A.N.; ALLEM, A.C. -Glossário de recursos genéticos vegetais. Brasília: Embrapa-SPI, 1996. $62 \mathrm{p}$.

VEGA O., P.C. Introduccion a la teoria de genetica cuantitativa: com especial referencia al mejoramiento de plantas. Caracas: Universidade Central de Venezuela, 1987. 400p.

VEIGA, R.D. A eficiência de dialelos circulantes avaliada em simulação de dados. Genetics and molecular biology, v.21, n.3, p.245, 1998.

VENCOVSKY, R. Alguns aspectos teóricos e aplicados relativos a cruzamentos dialélicos de variedades. Piracicaba, 1970. 59p. Tese (LivreDocência) - Escola Superior de Agricultura "Luiz de Queiroz", Universidade de São Paulo.

VERMA, S.; KUMAR, J.C.; CHADHA, M.L. Heterosis studies in brinjal (Solanum melongena L.). Progressive Horticulture, v.18, n.3/4, p.213-215, 1986.

VIANA, J.M.S.; CARDOSO, A.A.; CRUZ, C.D., REGAZZI, A.J.; DEL GIUDICE, R.M. Genetic divergence in sugar cane (Saccharum spp.) clones. Revista Brasileira de Genética, v.14, n.3, p.753-763, 1991.

ZEVEN, A.C; MOHAMED, H.H.; WANINGE, J.; VEURINK, H. Phenotypic variation within a Hungarian landrace of runner bean (Phaseolus coccineus L.). Euphytica, v.68, n.1/2, p.155-166, 1993.

WEIR, B.S. Genetic data analysis II. Sunderland: Sinauer Associates, 1996. $445 p$. 
WRIGHT, S. Variability within and among natural populations. Chicago: University of Chicago press, 1978. v.2, 580p. 